\title{
Dynamic analysis and field investigation of a fluidized landslide in Guanling, Guizhou, China
}

\section{$\operatorname{AUTHOR}(\mathrm{S})$ :}

Xing, A.G.; Wang, G.; Yin, Y.P.; Jiang, Y.; Wang, G.Z.; Yang, S.Y.; Dai, D.R.; Zhu, Y.Q.; Dai, J.A.

\section{CITATION:}

Xing, A.G....[et al]. Dynamic analysis and field investigation of a fluidized landslide in Guanling, Guizhou, China. Engineering Geology 2014, 181: 1-14

\section{ISSUE DATE:}

2014-10

URL:

http://hdl.handle.net/2433/189863

\section{RIGHT:}

C 2014 Elsevier B.V.; この論文は出版社版でありません。引用の際には 出版社版をご確認ご利用ください。; This is not the published version. Please cite only the published version. 
4

5

6

7

8 Authors:

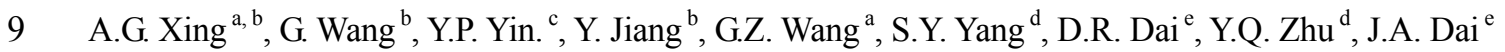

10 Addresses of authors:

11 Aiguo Xing, Associate Professor (Corresponding author)

$12{ }^{a}$ State Key Laboratory of Ocean Engineering, Shanghai Jiao Tong University, Shanghai, 200240, P.R.

13 China

$14 \quad{ }^{\mathrm{b}}$ Research Center on Landslides, Disaster Prevention Research Institute, Kyoto University, Uji,

15 611-0011, Japan

$16{ }^{\mathrm{c}}$ China Institute of Geo-Environment Monitoring, Beijing, 100081, P.R. China

$17{ }^{\mathrm{d}}$ Guizhou Institute of Geo-Environment Monitoring, Guiyang, Guizhou 550004, P.R. China

$18{ }^{\mathrm{e}}$ Guizhou Institute of Geophysical and Geochemical Prospecting, Guiyang, Guizhou 550005, P.R. China 
Dynamic analysis and field investigation of a fluidized landslide in Guanling, Guizhou, China

${ }^{a}$ State Key Laboratory of Ocean Engineering, Shanghai Jiao Tong University, Shanghai, 200240, P.R.

${ }^{\mathrm{b}}$ Research Center on Landslides, Disaster Prevention Research Institute, Kyoto University, Uji, 611-0011, Japan

${ }^{c}$ China Institute of Geo-Environment Monitoring, Beijing, 100081, P.R. China

${ }^{\mathrm{d}}$ Guizhou Institute of Geo-Environment Monitoring, Guiyang, Guizhou 550004, P.R. China

${ }^{\mathrm{e}}$ Guizhou Institute of Geophysical and Geochemical Prospecting, Guiyang, Guizhou 550005, P.R. China

Abstract: On June 28, 2010, a large catastrophic landslide was triggered by a heavy rainfall in

Guanling, Guizhou, China. This catastrophic event destroyed two villages and caused 99 casualities.

The landslide involved the failure of about $985,000 \mathrm{~m}^{3}$ of sandstone from the source area. The displaced materials travelled about 1, $300 \mathrm{~m}$ with a descent of about $400 \mathrm{~m}$, covering an area of 129 , $000 \mathrm{~m}^{2}$ with the final volume being accumulated to be $1,840,000 \mathrm{~m}^{3}$, approximately. To provide information for hazard zonation of similar type of landslides in the same area, we used a dynamic model (DAN3D) to simulate the runout behavior of the displaced landslide materials, and found that a combined frictional-Vollemy model could provide the best performance in simulating this landslide and the runout is precisely duplicated with a dynamic friction angle $(\phi)$ of $30^{\circ}$ and a pore pressure ratio $\left(r_{u}\right)$ of 0.55 for the materials at the source area and with Vollemy parameters of friction coefficient $f=$ 0.1 (dimensionless) and turbulent coefficient $\xi=400 \mathrm{~m} / \mathrm{s}^{2}$. The simulated results indicated that the duration of the movement is estimated at about $60 \mathrm{~s}$ for a mean velocity $23 \mathrm{~m} / \mathrm{s}$. To examine the effectiveness of simulation by means of DAN3D and also to evaluate the reactivation potential of 
43 Tomography (ERT) method to survey the depth and internal structure of landslide deposits. The ERT results showed that DAN3D gave a good prediction on the shape and runout distance of the landslide deposits, although the predicted maximum depths of landslide deposit on some areas were differing from those obtained by ERT method.

47 Keywords: Fluidized landslide; Landsliding; Dynamic analysis; Internal structure; Electrical resistivity 48 tomography 


\section{Introduction}

In the past few years, a lot of landslides, especially those featured by high mobility, were triggered frequently by heavy rainfall, earthquake and human activity in Southwestern China (Huang, 2009; Xu et al., 2009; Chigira et al., 2010; Yin, 2011; Yin et al., 2011a,b; Yin and Xing, 2012). By now, Chinese government has paid a lot of efforts in the prevention and mitigation of such kind of landslide hazards, through setting up geohazard early-warning system together with weather forecasting, geohazard education for local residents in mountainous areas, and national wide geohazard mapping, etc. These efforts effectively helped early identification of some landslides and enabled evacuation in time. Nevertheless, due to our poor understanding on the initiation and movement mechanisms of differing types of landslides, and also due to the continue development in mountainous areas as well as due to the climate change, landslides are still causing increasing losses of lives and properties in China.

How to prevent or mitigate disaster caused by landslides with high mobility is an urgent problem. Therefore, prediction of the character of the landslide, such as the possible velocity of the mass, the area of deposition, and volume of the moving soil mass, is of great importance in landslide risk assessment. Many numerical studies have been performed to obtain better understanding of landslides, and some rational approaches have been proposed for predicting the motion of landslide masses (e.g. Li, 1983; Sassa, 1988; Hungr, 1995; Crosta et al., 2003; Mangeney-Castelnau et al., 2003; Cleary and Prakash, 2004; McDougall and Hungr, 2004, 2005; Pirulli et al., 2004, 2008). By now, although the effectiveness of these approaches had been validated by the back-analyses of many landslides, successful forecasting of landslide movement has been rarely reported, because different models or parameters in these approaches should be used for differing types of landslides. However, back-analyses of case histories are essential, because successful back-analyses may be used to calibrate 
the models, improve forecasting accuracy, and also provide parameters specific to same type of rapid landslides for use in predictive modeling of potential landslides.

On the other hand, as pointed out by Strom (2006), developing reliable models for the movement and deposition of landslide mass needs to take into account the topographical, structural and depositional features, and the observable phenomena should be regarded as constraints with which to check the reliability of the numerical model. Because the witnesses of rapid movement of large landslides are rare (Sosio et al., 2008) and the deposits of large landslides usually exhibit complex geometries and grain size distributions (Crosta et al., 2007), it is still difficult to carry out a full validation of a given model.

Understanding the landslide deposits is not only essential to the back analysis of landsliding, but also of great importance for secondary hazard assessment. For example, the $2008 \mathrm{M}_{\mathrm{w}} 7.9$ Wenchuan earthquake triggered more than 60,000 landslides (Gorum et al., 2011), and a huge amount of landslide mass deposited on the slope enabled the occurrence of numerous post-seismic debris flows, resulting in further loss of lives and great damages to many newly-constructed towns and facilities (Parker et al., 2011; Tang et al., 2012). Recently, effort had been made to understand the formation of landslide deposits. For example, geophysical survey methods had been used to retrieve information on both the rupture and deposits zones (McGuffey et al., 1996; Green et al., 2006; Jongmans and Garambois, 2007; Socco et al., 2010; Wang et al., 2013). Among those geophysical survey methods, Electrical Resistivity Tomography (ERT) had been proved to a reliable and promising technique, and had been used to reconstruct the geometry of landslide bodies, outline the sliding surface, estimate the thickness of sliding material and volume, and evaluate the area with high water content (Bichler et al., 2004; Perrone et al., 2004; Gokturkler et al., 2008; Chambers et al., 2009). 
In this study, we used a numerical model to analyze the runout behavior of a catastrophic landslide occurred in Guanling, Guizhou, China (hereinafter termed Guanling landslide) (Fig. 1). We also used ERT to measure the distribution of landslide deposits and the internal structure of the landslide introduced in this study to check the suitability of using DAN3D for the landsliding evaluation in Southwestern China and also to provide reliable information for the possible secondary hazard assessment.

Guanling landslide was triggered by a heavy rainfall on $14: 30$ of June 28,2010 . The displaced landslide material destroyed two villages and killed 99 people. We analyzed the landsliding by using a dynamic model, DAN3D, developed by Hungr and his colleagues (Hungr, 1995; McDougall and Hungr, 2004, 2005). Through the numerical analysis, the most suitable rheological models and parameters were calibrated and validated based on the estimation of velocities from run-up and superelevation. It is expected that these models and parameters could elevate the precision of hazard zonation for areas with geological, topographical and climatic features being similar to Guanling landslide area. Because all the displaced landslide materials deposited on the valley, still threatening the safety of residents living on the downstream of the valley, better understanding on the spatial distribution of the thickness of deposited materials as well as their internal structure will be of great importance. Also for hazard zonation of this type of landslides in the same area, forecasting the movement and final deposition area will be essential. Hence, we also applied the Electrical resistivity tomography (ERT) method to assess the depth and internal structure of the Guanling landslide deposit,

\section{Geological and climatic setting}

Guanling landslide occurred on a region of middle-mountain relief (730-1642 m a.s.1.) with deeply 
115

incised valley. The upper valley is characterized by steep slopes ranging from 25 to 35 degrees, while the lower part of the valley by gentle slopes of 10 to 15 degrees.

The exposed rocks in the study area range in age from late Permian to Quaternary (Fig. 2). The landslide occurred in the Early Triassic Yelang sandstone, which is overlain by the Early Triassic Yongningzhen limestone and underlain by the Late Permian Longtan sandy shale. The rock on the source area dips regularly toward the south with a dip angle of $40^{\circ}$. The Yelang Formation stratum is a discordant contact with the Longtan Formation, which forms a hard rock structure overlaying the soft rock.

In terms of the tectonic framework, the study area is located at the south flank of Yongning anticlinorium and the north flank of the Guanling synclinorium. The landslide is in the anti-dip slope of cuesta topography. The major joint sets are present at $315^{\circ} / 64^{\circ}(\mathrm{J} 1), 220^{\circ} / 70^{\circ}(\mathrm{J} 2), 60^{\circ} / 85^{\circ}(\mathrm{J} 3)$, $295^{\circ} / 85^{\circ}(\mathrm{J} 4)$, and $20^{\circ} / 70^{\circ}(\mathrm{J} 5)$ and the bedding plane is $185^{\circ} / 35^{\circ}$, resulting in cutting the rock mass into blocks (Fig. 3). The joint set of $315^{\circ} / 64^{\circ}$ is approximately parallel to the surface of rupture with an attitude of $325^{\circ} / 75^{\circ}$. The structure surfaces and combination of them are one of the major control factors of the landslide.

According to the occurrence of groundwater in rocks, the groundwater in the study area can be divided into three types: Carbonatite karst water, bedrock fissure water, and pore water in Quaternary loose deposits.

Carbonatite karst water mainly occurs in the limestone and dolomite layers of the Yongningzhen Formation of Triassic, which is located at the outer edge of the main scarp of the landslide. It usually discharges through the springs at the contact zone between the Yongningzhen Formation and the underlying Yelang Formation. The spring water discharge fluctuations are primarily due to variations in 
rainfall in recharge area and the spring has a very high yield during the rainy season.

Bedrock fissure water mainly occurs in the joints and weathering fissures of the Yelang Formation fragmentary rock and the Emei Mountain basalt. The water is in good hydraulic connection with the upper karst water and is mainly fed by the migration of fissure water and karst conduit flow. Part of the water discharges through the springs into the gully, other part migrates through cracks and joints and discharges in an area of low relief and the final drainage datum is the Beipan river.

Pore-water in Quaternary loose deposits mainly occurs in the old rockfall deposits at the two sides of the valley and is mainly fed by rainfall. Part of the water infiltrates into the Permian pyroclastic rocks and other part recharges laterally the gully. The water fluctuations can be large.

This region has a humid subtropical monsoon climate with the average annual temperature being about $16.2^{\circ} \mathrm{C}$. The annual rainfall ranges from 1205 to $1657 \mathrm{~mm}$ and $84.0 \%$ of the precipitation occurs during the rainy season (from May to September). However, in June of 2010, heavy rain fell on this area, and a rain gauge in Gangwu town (about $6 \mathrm{~km}$ southeast of the landslide area), Guanling County, measured a cumulative rainfall of $550 \mathrm{~mm}$ from June $1^{\text {st }}$ to $30^{\text {th }}, 2010$, which is 1.78 times greater than the average rain of June from 1996 to 2005. The maximum daily rainfall recorded on June 28 was 260 $\mathrm{mm}$, which exceeded the historical record of this area (Fig. 4).

\section{Guanling landslide}

An aerial image and a topography map of the landslide are presented in Fig. $1 \mathrm{~b}$ and Fig. 5, respectively.

Fig. 6 shows a view of the source area. After detaching from its source area, the landslide material ran down rapidly in a direction $35^{\circ}$ west of north, traveled across the valley floor, with its frontal part running up the opposite slope at location "A" in Fig. 1b, and then falling back into the valley after 
159

160

destroying 21 houses in the Yongwo village (location "A" in Fig. 1b). The slide transformed into flow and changed its direction by $75^{\circ}$ along the valley floor. Some debris ran up the slope on the left side of the valley and damaged part of the pine forest (Fig. 6). Most of the debris traveled down along the valley and further destroyed 17 houses in the Dazhai village (location "B" in Fig. 1b) due to the superelevation on the bend of the valley. The debris continued to move along the valley in a direction $75^{\circ}$ west of south and finally came to rest at the mouth of the valley (Fig. 5).

The source area is located at the transition zone of the upper steep carbonatite (with the gradient $>$ $80^{\circ}$ ) and the lower sandy shale of Longtan formation (with the gradient being $15-25^{\circ}$ ). The head scarp and the toe of the rupture surface are 1,180 m and $950 \mathrm{~m}$ in elevation, respectively. The source area has a width of 150-200 $\mathrm{m}$ and a thickness of 50-70 m (Figs. 5 and 7a).

The displaced materials mainly deposited at elevations ranging from 1, $120 \mathrm{~m}$ to $780 \mathrm{~m}$ (Fig. 5). The parent rock of the debris is the Early Triassic Yelang sandstone. The deposition area can be divided into four subzones according to grain size distribution: boulders dominant subzone (Zone e), gravels dominant subzone (Zone f), Silty soils dominated subzone (with gravels in small size) (Zone g), and mudflow deposition subzone (Zone h) (Fig. 5). It is noted that the materials on Zones e-g were originated from the landslide source area, whereas the materials in Zone $\mathrm{h}$ resulted from the transportation of old residual soil of the valley and is mainly composed of fine-grained soils with layered structure caused by several times of mudflow events, and the thickness of the deposits in this zone is about $5 \mathrm{~m}$.

The boulders dominant zone is in the lower part of the source area and eastern margin of upper part of debris flow deposition area. This subzone has a longitudinal length of $235 \mathrm{~m}$ in the direction $55^{\circ}$ west of north, a width of 35 to $50 \mathrm{~m}$ and an area of $10,575 \mathrm{~m}^{2}$. The boulder ranges in size from $20 \mathrm{~cm}$ 
181

to $200 \mathrm{~cm}$ and the largest boulder has a volume of $3.75 \mathrm{~m}^{3}$.

The gravels-dominant subzone is located at the northwestern margin of middle-upper part of deposition area. The subzone has a longitudinal length of $400 \mathrm{~m}$, a width of 90 to $200 \mathrm{~m}$ and an area of $73,600 \mathrm{~m}^{2}$. The gravels range in size from $2 \mathrm{~cm}$ to $20 \mathrm{~cm}$.

The silty soils dominant subzone is in the lower part of debris flow deposition area. The area has a longitudinal length of $500 \mathrm{~m}$ and a width of 60 to $100 \mathrm{~m}$ with an area of $44,800 \mathrm{~m}^{2}$. The gravels range in size from $0.2 \mathrm{~cm}$ to $5 \mathrm{~cm}$. The deposits consisted of 30 to 40 percent silty soils and above 50 percent gravels. The grain size distribution of silty soil sample is presented in Fig. 8 .

The mudflow deposit zone is formed by the transportation of old residual soils and is mainly composed of clay soils, with a prominent layered structure caused by multi-period mudflows. According to field investigation, we can found that the displaced materials deposited above the mudflow deposits (Fig. 7e). The current mudflow deposit thickness is about $5 \mathrm{~m}$.

\section{Landsliding analysis}

\subsection{The dynamic model}

Dynamic back analysis can be empirical, using historical data like volume, fall height, runout, etc. (e.g. Scheidegger, 1973; Corominas, 1996), and/or numerical simulation to analyze the runout behavior of the fluidized landslide (Hungr et al., 2005).

In this paper, we used a dynamic model DAN3D developed by Hungr and his colleagues (Hungr et al., 2005; McDougall and Hungr, 2004) to simulate the behavior of this landslide. This model is based on numerical solutions of the depth averaged shallow water equations, which have been modified for the flow of earth materials. The model utilizes a meshless numerical method, based on smoothed 
203

204

particle hydrodynamics $(\mathrm{SPH})$ which permits the simulation of motion across a real 3D topography without mesh distortion problem, making it suitable for the back analysis of fluidized landslides. Consistent with the equivalent fluid approach formalized by Hungr (1995), simulation of a catastrophic event is achieved through trial and error by systematically modifying the parameters that govern the basal resistance until the characteristics of the simulated landslide (i.e., velocity, extent and depth of deposits) approximately match those of the real event (McDougall and Hungr, 2005).

The dynamic model is governed by internal and basal rheological relationships. The rheologies that have been found to represent recorded events most accurately are the frictional and Vollemy rheologies. The frictional rheology assumes the resisting shear force $(\tau)$ to depend only on the effective normal stress $(\sigma)$. The frictional equation is expressed as:

$$
\tau=\sigma\left(1-r_{u}\right) \tan \phi
$$

where the pore pressure ratio, $r_{u}$, and the dynamic friction angle, $\phi$, are the rheological parameters to be introduced in the model. The pore pressure ratio derives from the pore pressure, $u$, normalized by the total bed normal stress at the base, $\sigma$. The pore-pressure ratio and the dynamic friction angle can be alternatively expressed by one single variable denoted as bulk basal friction angle, $\phi_{b}$ :

$$
\phi_{b}=\arctan \left(1-r_{u}\right) \tan \phi
$$

$$
\text { The Voellmy rheology describes the total resistance as a sum of a frictional and a turbulent term: }
$$

$$
\tau=\sigma+\rho g v^{2} / \xi
$$

$$
\text { The frictional term relates the shear stress to the normal stress through a friction coefficient, } f \text {, }
$$

which is analogous to $\tan \phi_{b}$. The turbulent term summarizes all velocity-dependent factors of flow resistance, and is expressed by the square of the velocity and the density of the debris through a turbulence coefficient, $\xi$. 


$$
v_{\min }=(2 g h)^{0.5}
$$

where $v_{\min }$ is the minimum velocity in $\mathrm{m} \cdot \mathrm{s}^{-1}, g$ is gravitational constant, and $h$ is the run-up height.

$$
v_{\min }=(g d r / b)^{0.5}
$$

where $v_{\min }$ is the minimum velocity in $\mathrm{m} \cdot \mathrm{s}^{-1}, g$ is gravitational constant, $d$ is the superelevation,

\subsection{Input data}

The input sliding surface and source thickness files were created using pre- and post-event DEMs at a scale of $1: 10,000$. The source depths were approximated by subtracting the post- from the pre-event DEM and isolating the probable main failure zone. Data outside of this zone were filtered, leaving a displaced volume of approximately $985,000 \mathrm{~m}^{3}$. The isolated source depths were then subtracted from the pre-event DEM to estimate the initial sliding surface elevations. Assuming a volume of $25 \%$ volume bulking as suggested by Hungr and Evans (2004), the total volume of displaced materials was estimated to be $1,230,000 \mathrm{~m}^{3}$. The data spacing was increased to $5 \mathrm{~m}$ for input into the model. 
Continuum simulation is achieved through discretization of the governing equations, but a

sufficiently large number of computational elements (particles) are required to capture the behavior at

every important location within the slide mass. Increasing the number of particles $(N)$ can increase the

resolution of the continuum method. Particle smoothing coefficient $(B)$ influences the smoothness of

appears smooth. Velocity smoothing coefficient $(C)$ determines how much the velocities of

stiffness coefficient $(D)$ controls the strain-dependent rate of the transition between active and passive pressure for all the simulations. 
simultaneously during the Guanling landslide. The basal rheological parameters were adjusted by trial and error to achieve the best fit with the observed extension of the landslide deposit, considering also some published values from comparable case studies (Hungr and Evans, 1996; McDougall et al., 2006; Evans et al., 2007; Sosio et al., 2008). A dynamic friction angle of $30^{\circ}$ was adopted for the frictional model, with pore pressure. We examined excess pore water pressure acting on the potential sliding surface at the source area because the sliding zone soil was fully saturated, equivalent to a range in pore pressure ratio $\left(r_{u}\right)$ of 0.5 to 0.8 , to simulate the frictional loss along the sliding surface resulting from the undrained loading. A Vollemy rheology was selected to characterize the runout behavior of debris flow below the elevation of $950 \mathrm{~m}$. For the simulation of this part of the path values for the friction coefficient $(f)$ in the range of $0.05-0.25$ together with a range of values for the turbulence coefficient $(\xi)$ of $400-500 \mathrm{~m} / \mathrm{s}^{2}$ were used. It noted that these values for the Vollemy parameters are within the range of those found to best simulate the run-out and velocity of the majority of rockslide-debris avalanche case histories analysed by Hungr and Evans (1996). These values were then used in a series of simulation runs to obtain the best fit for the observed characteristics of the Guanling landslide.

Mass and momentum transfer during entrainment of path material can have an important influence on landslide dynamics. A useful preliminary estimate of the average volume growth rate $\left(\overline{E_{s}}\right)$ for a specific entrainment zone can be obtained from the following natural exponential growth equation (McDougall and Hungr, 2005):

$$
V_{f}=V_{0} \exp \left(\overline{E_{s}} \bar{S}\right)
$$

Where $V_{f}$ is the estimated total volume of the landslide exiting the zone, $V_{0}$ is the estimated total volume of the landslide entering the zone and $\bar{S}$ is the approximate average path length of the zone. Given the initial and final volumes, as observed, and the approximate length of the entrainment zone, 
291 the appropriate rate to use in a simulation can be back-calculated using the Equation (6), which ensures that the required volume is entrained from the known length of the entrainment zone (cf. McDougall and Hungr 2005). In this case, the volumes entering and exiting the entrainment zone were taken as $1,230,000$ and $1,840,000 \mathrm{~m}^{3}$, respectively. The valley length within the entrainment zone was taken as $900 \mathrm{~m}$. Hence, to simulate entrainment, a volume growth rate of $4.5 \times 10^{-4} \mathrm{~m}^{-1}$ was specified below the elevation of $950 \mathrm{~m}$.

\subsection{Results and discussion}

A sensitivity analysis was performed in order to define the best rheological parameters for the simulation (Tab. 1). The results of the DAN3D simulation are seen in Fig. 9. The runout is precisely duplicated with a dynamic friction angle $(\phi)$ of $30^{\circ}$ and a pore pressure ratio $\left(r_{u}\right)$ of 0.55 for the materials at the source area and with Vollemy parameters of friction coefficient $f=0.1$ (dimensionless) and turbulent coefficient $\xi=400 \mathrm{~m} / \mathrm{s}^{2}$ at the flow and deposition area. The results show that landsliding experienced $60 \mathrm{~s}$. In the following $120 \mathrm{~s}$ (from 60 to $180 \mathrm{~s}$ ), only lateral spreading of the deposited debris was observed. The simulated run-up at the Yongwo village and superelevation at the Dazhai village simulated.

A plot of the maximum simulated flow velocities recorded along the runout path is shown in Fig. 10. The maximum velocity, up to about $50 \mathrm{~m} / \mathrm{s}$, was recorded at the toe of the source area. As mentioned above, the possible velocities were also calibrated by means of run-up and superelevation. yields a velocity estimate of $28 \mathrm{~m} / \mathrm{s}$ for a measured run-up of $h=40 \mathrm{~m}$. At elevation $800 \mathrm{~m}$, the debris 
313

314

315

parameters of $d=20 \mathrm{~m}, r=200 \mathrm{~m}$, and $b=80 \mathrm{~m}$. The locations and estimated velocities are superimposed in Fig. 12. The compared results show that the usage of turbulence parameter as $400 \mathrm{~m} / \mathrm{s}^{2}$ gave us a best match for the velocities estimated using both run-up and superelevation data.

Based on the DAN model, a large number of case studies of rapidly moving landslides in North America have been analyzed and a valuable database of calibrated parameters has been created (cf. Hungr et al., 2005). Further case studies will be performed using the DAN model to obtain the usable rheological parameters for conducting landslide hazard assessment in the mountainous areas of southwestern China. As a mission of future studies, we are expecting to incorporate the spatially-varied parameters in the DAN model to elevate its capacity in the prediction of the internal structure of the landslide deposits also.

\section{Geophysical investigation of the depth and internal structure of deposits}

In this work, three longitudinal profiles (ERT1-ERT3) and five transverse profiles (ERT4-ERT8) were measured to get more detailed information on the depth and internal structure of the landslide deposits.

The locations of these profiles (ERT1-ERT8) are indicated in Fig. 5. ERT1 mainly passes through zone $\mathrm{g}$ (consisting of silty with gravels in small size), ERT2 through both zones $g$ and $\mathrm{f}$ (consisting of gravel-sized debris), and ERT3 passes through zone f. ERT4 passes through zone g (consisting of silty with gravels in small size), while other four transverse profiles (ERT5- ERT8) pass through both zone e (consisting of boulder-sized debris) and zone $\mathrm{f}$ (consisting of gravel-sized debris).

Wenner electrode array was employed for the resistivity measurements and the resulting apparent resistivity pseudosection was transformed into a model representing continuous distribution of calculated electrical resistivity in the subsurface by RES2Dinv software (Loke and Barker, 1996). 
Knowledge of local geology, associated with high spatial resolution of the measurements, gave us

an interpretative tool to explain the ERTs obtained for Guanling landslide. According to the magnitude,

morphology, variation trend of the apparent resistivity and comparison with the borehole data, we can

determine the boundary between the deposition and bed rocks. In this work, we found that high

resistivity anomaly could be associated with the landslide deposits, whereas the relatively

low-resistivity zone is considered to reflect the bedrock outcrops or Quaternary deposits. Therefore,

from the vertical distribution of high resistivity anomaly, we can infer that the depth of the landslide deposits.

In order to validate the effectiveness of the ERT method, five boreholes were drilled along the ERT-V line. All the five boreholes were dry when the ERT investigation was conducted in April, 2011.

The results show that the thickness of landslide deposit detected by ERT roughly agrees with the borehole data, as shown in Fig. 11, indicating that the ERT method can be used to examine the depth and internal structure of landslide deposit. The inverse model resistivity sections are presented in Figs. 12 and 13, for these longitudinal profiles (ERT1-ERT3) and transverse profiles (ERT4-ERT8), respectively.

In Fig. 12a, high resistivity anomalies are noticed at the distances of 80 to $260 \mathrm{~m}$ and 300 to $480 \mathrm{~m}$ from the origin of the profile, with the maximum resistivity value $>300 \mathrm{ohm} \cdot \mathrm{m}$. The depth of the landslide deposits ranges from 5 to $20 \mathrm{~m}$ with the maximum deposit thickness being near the distance of $180 \mathrm{~m}$ from the origin of the survey line. From Fig. 12b we can see that high resistivity anomaly is located on the area $160-840 \mathrm{~m}$ far from the origin of the profile, with a maximum resistivity value $>1$, 
of ERT3 (Fig. 12c), high resistivity anomaly is seen at the distance of 75 to $280 \mathrm{~m}$ far from the origin, with the maximum resistivity value $>400 \mathrm{ohm} \cdot \mathrm{m}$. The depth of the landslide deposits ranges from 4 to $30 \mathrm{~m}$ with the maximum deposit thickness being located at the distance of 120 to $160 \mathrm{~m}$.

The transverse ERT profiles revealed that the thickness of landslide deposits is differing at different profiles and also at different positions of the same profile. As shown in Fig. 13a, high resistivity anomaly appears on the region 115 to $140 \mathrm{~m}$ far from the origin of the profile ERT4 and the thickness of the landslide deposits ranges from 5 to $10 \mathrm{~m}$ with the maximum deposit thickness being near the distance of $120 \mathrm{~m}$. Fig. 13b shows that the landslide deposits are located between 140 to $190 \mathrm{~m}$ far from the origin of the profile with the thickness ranging from 2 to $16 \mathrm{~m}$. It is noted that this profile shows a maximum resistivity value $>1,800 \mathrm{ohm} \cdot \mathrm{m}$.

ERT6 (Fig. 13c) revealed a large area of landslide deposits locating between the distance of $80-220 \mathrm{~m}$ from the origin of the profile with the thickness ranging from 3 to $30 \mathrm{~m}$. Similarly ERT7 (Fig.13d) also gives a wide distribution of landslide deposits. It has a width of about $145 \mathrm{~m}$ (locating between the distances of 15 and $160 \mathrm{~m}$ from the origin), and a varying thickness ranging from 2 to 18 m. In Fig. 13e, the landslide deposits have a width of about $150 \mathrm{~m}$ (locating between $35 \mathrm{~m}$ and $185 \mathrm{~m}$ far from the origin). The thickness of the deposits is inferred to be ranging from 10 to $35 \mathrm{~m}$, with the maximum deposit thickness being located on a wide area between the distance $120 \mathrm{~m}$ and $160 \mathrm{~m}$ from the origin of the survey line. It is also noted that the maximum depth (about $35 \mathrm{~m}$ ) shown in Fig. 11 is a reasonable value, because the maximum depth by means of this kind of survey method could be roughly $1 / 6$ of the survey line theoretically (Saas, 2006; Saas et al., 2008).

Fig. 14 presents the final distribution of the debris given by the DAN3D simulation. It is estimated that the landslide deposits has an average depth of about $17 \mathrm{~m}$ and a maximum depth of 
379

380 movement will be needed to make a conclusive remarking on this aspect. that DAN3D model regards the landslide mass as equivalent fluid. post-event topography.

over 35 m. Based on Figs. 12-14, Tab. 2 and Fig. 15 present the comparison between the depths of landslide deposits obtained by ERT interpretation and DAN3D simulation along those ERT lines shown in Fig.14. From Tab. 2 we can see that the depths of landslide deposits estimated by DAN3D simulation are roughly consistent with those estimated by means of ERT, irrespective of the relatively big differences appeared along the ERT-V and ERT8 profiles. As shown in Fig. 15, DAN3D also gave a good prediction on the shape of the landslide deposits, although the depths of landslide deposit were underestimated due to longitudinal and lateral spreading. These differences may result from the fact

These detailed ERT survey results enabled us to estimate the thickness of landslide deposits and then provide a profile of the landslide with the original ground surface being inferred from the

The ERT method had been applied to identify the landslide mass and sliding surface and the results showed that shallow conductive layer could be associated with displaced landslide material, deep resistive zone with the bedrocks (Colangelo et al., 2008). However, from Figs. 12 and 13, we found that the high resistivity anomaly is associated with the landslide deposit, and low resistivity anomaly with the bedrock or Quaternary deposits. This may result from the high porosity of landslide deposits, because the displaced landslide materials deposited loosely after long runout of movement. In this study, the influence of groundwater condition on the spatial distribution of resistivity was not involved because the materials mainly consisted of dry, broken rock about ten months after the event. Nevertheless, further examination on similar landslide deposits suffering from rapid long runout 


\section{Summary and conclusions}

402

403

On June 28, 2010, a catastrophic landslide was triggered by heavy rainfall in Guanling, Guizhou, China and killed 99 people. Based on the field investigation, this paper introduced the setting, and analyzed the deposit features, dynamic characteristics of this landslide through electrical resistivity tomography (ERT) method and dynamical process simulation.

A recently developed dynamic model (DAN3D) that accounts for material entrainment along the runout path was used to simulate the runout behavior of this event. The sliding velocity and depositing area were modeled using different basal rheologies: a frictional model in the source area and a Voellmy model in the debris flow and deposition area. The DAN3D simulation gave a good prediction on the shape of the landslide deposits and runout distance. Very good agreement between the observed and simulated results was achieved, suggesting that this model with the parameters obtained through back analyses could be a strong tool for the prediction of landsliding in the same area, and then to mitigate this kind of landslide hazard.

The results of the ERT surveys have confirmed the possibility of applying the resistivity anomaly to characterize the landslide deposit in order to obtain an internally consistent site model, and also further proved the effectiveness of using DAN3D in the sliding prediction of Guanling landslide.

\section{Acknowledgment}

This study was supported by the National Natural Science Foundation of China (No.40602035 and 41272382) and National Science Fund for Distinguished Young Scholars (No. 41225011). The DEM data used in the analysis were provided by Prof. Shengyuan Yang (Institute of Geo-Environmental Monitoring of Guizhou, China). Finally, our special thanks go to our three anonymous reviewers and 
423

424

425

426

427

Prof. Juang for their valuable comments that substantially improved this paper.

\section{References}

Bichler, A., Bobrowsky, P., Best, M., Douma, M., Hunter, J., Calvert, T., Burns, R., 2004. Three-dimensional mapping of a landslide using a multi-geophysical approach: the Quesnel Forks landslide. Landslides 1 (1), 29-40.

Boultbee, N., 2005. Characterization of the Zymoetz River rock avalanche. M.Sc. thesis, Simon Fraser University, Vancouver.

Chambers, J.E., Meldrum, P.I., Gunn, D.A., Wilkinson, P.B., Kuras, O., Weller, A.L., and Ogilvy, R.D., 2009. Hydrogeophysical monitoring of landslide processes using Automated Time-Lapse Electrical Resistivity Tomography (ALERT). In Proceedings, 15th Annual Meeting EAGE-Near Surface Geophysics, Dublin, 7-9 September, 2009.

Chigira, M., Wu, X.Y., Inokuchi, T., Wang, G.H., 2010. Landslides induced by the 2008 Wenchuan earthquake, Sichuan, China. Geomorphology 118 (3-4), 225-238.

Cleary, P.W., Prakash, M., 2004. Discrete-element modelling and smoothed particle hydrodynamics: potential in the environmental sciences. Philosophical Transactions of the Royal Society A: Mathematical, Physical and Engineering Sciences 362, 2003-2030.

Colangelo G., Lapenna V., Loperte A., Perrone A., Telesca L, 2008. 2D electrical resistivity tomographies for investigating recent activation landslides in Basilicata Region (Southern Italy), Annals of Geophysics 51 (1), 275-285.

Corominas, J., 1996. The angle of reach as a mobility index for small and large landslides, Canadian Geotechnical Journal 33, 260-271. 
Crosta, G.B., Imposimato, S., Roddeman, D.G., 2003. Numerical modelling of large landslides stability and runout. Natural Hazards and Earth System Sciences 3 (6), 523-538.

Crosta, G.B., Frattini, P., Fusi, N., 2007. Fragmentation in the Val Pola rock avalanche, Italian Alps. Journal of Geophysical Research 112 (F1), F01006.

Crozier, M.J., 2010. Deciphering the effect of climate change on landslide activity: a review. Geomorphology 124: 260-267.

Evans, S.G., Hungr, O., Clague J.J., 2001. Dynamics of the 1984 rock avalanche and associated distal debris flow on Mount Cayley, British Columbia, Canada; implications for landslide hazard assessment on dissected volcanoes. Engineering Geology, 61:29-51.

Evans, S.G., R. H. Guthrie, R.H., Roberts, N.J., Bishop, N.F., 2007. The disastrous 17 February 2006 rockslide-debris avalanche on Leyte Island, Philippines: a catastrophic landslide in tropical mountain terrain. Natural Hazards and Earth System Sciences 7, 89-101.

Godio, A., Strobbia, C., De Bacco, G., 2006. Geophysical characterisation of a rockslide in an alpine region. Engineering Geology 83, 273-86.

Göktürkler, G., Balkaya, Ç., Erhan, Z., 2008. Geophysical investigation of a landslide: The Altındağ landslide site, İzmir (western Turkey): Journal of Applied Geophysics, 65, 84-96.

Gorum, T., Fan, X.M., van Westen, C.J., Huang, R.Q., Xu, Q., Tang, C., Wang, G.H., 2011. Distribution pattern of earthquake-induced landslides triggered by the 12 May 2008 Wenchuan earthquake. Geomorphology 133 (3-4), 152-167.

Green, A.G., Maurer, H.R., Spillmann, T., Heincke, B., Willenberg, H., 2006. High resolution geophysical techniques for improving hazard assessments of unstable rock slopes. The Leading Edge 25 (3), 311-316. 
Huang, R.Q., 2009. Some catastrophic landslides since the twentieth century in the southwest of China. Landslides 6 (1), 69-81.

Huggel, C., Clague J.J., Korup, O., 2012. Is climate change responsible for changing landslide activity in high mountains? Earth Surface Processes and Landforms 37, 77-91.

Hungr, O., 1995. A model for the runout analysis of rapid flow slides, debris flows, and avalanches. Canadian Geotechnical Journal 32 (4), 610-623.

Hungr, O., Evans, S.G., 1996. Rock avalanche run out prediction using a dynamic model. In: Senneset (Ed.), Landslides; Proc. intern. symp., Trondheim, vol. 1, pp. 233-238.

Hungr, O., McDougall, S., Bovis, M., 2005. Entrainment of Material by Debris Flows. In: Jakob \& Hungr (eds.): Debris Flow Hazards and Related Phenomena. pp. 135-158. Heidelberg: Springer.

Hungr, O., Corominas, J., and Eberhardt, E., 2005. "Estimating landslide motion mechanism, travel distance and velocity." Landslide Risk Management, Proceedings, Vancouver Conference, State of the Art Paper \#4, In: Hungr, O., Fell, R., Couture, R. and Eberhardt, E. (eds.), Taylor and Francis Group, London, pp. 99-128.

Jongmans, D., Garambois, S., 2007. Geophysical investigation of landslides: a review. Bulletin de la Société Géologique de France 178 (2), 101-112.

Lapenna, V., Lorenzo, P., Perrone, A., Piscitelli, S., Rizzo, E., Sdao, F., 2005. Case history: 2D electrical resistivity imaging of some complex landslides in Lucanian Apennine (Southern Italy). - Geophysics 70, B11-B18.

Li, T.C., 1983. A mathematical model for predicting the extent of a major rockfall, Zeitschrift fur Geomorphologie 27 (4), 473-482.

Loke, M.H., Barker R.D.,1996. Rapid least-squares inversion of apparent resistivity pseudosections 
using a quasi-Newton method. Geophysical Prospecting 44, 131-152.

Mangeney-Castelnau, A., Vilotte, J.P., Bristeau, M.O., Perthame, B., Bouchut, F., Simeoni, C., Yerneni, S., 2003. Numerical modeling of avalanches based on Saint Venant equations using a kinetic scheme. Journal of Geophysical. Research 108 (B11), 2527.

McDougall S., Hungr O., 2004. A model for the analysis of rapid landslide motion across three-dimensional terrain. Canadian Geotechnical Journal 41 (6), 1084-1097.

McDougall S., Hungr O., 2005. Dynamic modelling of entrainment in rapid landslides. Canadian Geotechnical Journal 42 (5), 1437-1448.

McDougall S., Boultbee N., Hungr O., Stead D., Schwab J.W., 2006. The Zymoetz River landslide, British Columbia, Canada: description and dynamic analysis of a rock slide-debris flow. Landslides 3, 195-204.

McGuffey, V., Modeer, J., Victor, A., Turner, A.K., 1996. Subsurface exploration. In: Turner, A.K., Schuster, R.L. (Eds.), Landslides: Investigation and Mitigation. National Academy Press, Washington, D.C., pp. 231-277.

Meric, O., Garambois, S., Jongmans, D., Wathelet, M., Chatelain, J.L., Vengeon, J.M., 2005. Application of geophysical methods for the investigation of the large gravitational mass movement of Sechilienne, France. Canadian Geotechnical Journal 42, 1105-1115.

Parker, R.N., Densmore, A.L., Rosser, N.J., de Michele, M., Li, Y, Huang, R.Q., Whadcoat, S., Petley, D. N., 2011. Mass wasting triggered by the 2008 Wenchuan earthquake is greater than orogenic growth. Nature Geoscience 4(7), 449-452.

Perrone, A., Zeni, G., Piscitelli, S., Pepe, A., Loperte, A., Lapenna, V., Lanari, R., 2006. Joint analysis of SAR interferometry and electrical resistivity tomography surveys for investigating 
Pirulli, M., Scavia, C., Hungr, O., 2004. Determination of rock avalanche run-out parameters through back analyses. In: Lacerda, W.A., Ehrlich, M., Fontoura, S.A.B., Sayão, A.S.F. (Eds.), Proceedings of the 9th International Symposium on Landslides, Rio de Janeiro. Balkema, London, pp. 1361-1366.

Pirulli, M., Mangeney, A., 2008. Results of back-analysis of the propagation of rock avalanches as a function of the assumed rheology. Rock Mechanics and Rock Engineering 41, 59-84.

Saas, O., 2006. Determination of the internal structure of alpine talus deposits using different Geomorphology 93, 89-103.

Sassa, K., 1988. Geotechnical model for the motion of landslides. In: Proc. 5th International Symposium on Landslides, “Landslides”, Balkema, Rotterdam, vol. 1. pp 37-56.

Scheidegger, A.E., 1973. On the prediction of the reach and velocity of catastrophic landslides. Rock Mech. 5, 231-236.

Socco, L.V., Jongmans, D., Boiero, D., Stocco, S., Maraschini, M., Tokeshi, K., Hantz, D., 2010. Geophysical investigation of the Sandalp rock avalanche deposits. Journal of Applied Geophysics

531 Sosio, R., Crosta, G.B., Hungr, O., 2008. Complete dynamic modeling calibration for the Thurwieser rock avalanche (Italian Central Alps). Engineering Geology 100 (1-2), 11-26. 
Strom, A., 2006. Morphology and internal structure of rockslides and rock avalanches: grounds and constraints for their modeling. In Evans, S. G., Mugnossa, G. S., Strom, A., Hermanns, R. L. (Eds): Landslides from Massive Rock Slope Failure, NATO Sciences Series, IV. Earth and Environmental Sciences, 49, 305-326.

Tang, C., van Asch T.W.J., Chang M., Chen G.Q., Zhao X.H. , Huang X.C., 2012. Catastrophic Debris flows on 13 August 2010 in the Qingping area, southwestern China: the combined effects of a strong earthquake and subsequent rainstorms. Geomorphology 139-140, 559-576.

Xu, Q., Fan, X.M., Huang, R.Q.,Yin, Y.P., Hou, S.S., Dong, X.J., Tang, M.G., 2010. A catastrophic rockslide-debris flow in Wulong, Chongqing, China in 2009: background, characterization, and causes. Landslides 7 (1), 75-87.

Yin, Y.P., 2011. Recent catastrophic landslides and mitigation in China. Journal of Rock Mechanics and Geotechnical Engineering 3 (1), 10-18.

Yin, Y.P., Sun, P., Zhang, M., Li, B., 2011a. Mechanism on apparent dip sliding of oblique inclined bedding rockslide at Jiweishan, Chongqing, China. Landslides 8(1), 49-65.

Yin, Y.P., Sun, P., Zhu, J.L., Yang, S.Y., 2011b. Research on catastrophic rock avalanche at Guangling, Guizhou, China. Landslides 8 (4), 517-525.

Yin Y.P., and Xing A.G., 2012. Aerodynamic modeling of the Yigong gigantic rock slide-debris avalanche, Tibet, China. Bulletin of Engineering Geology and the Environment 71(1), 149-160. 


\section{Captions:}

553 Fig. 1. (a) Location of Guanling landslide; (b) Aerial view of Guanling landslide, where the red arrows express the landsliding direction; A and B: locations of Yongwo and Dazhai villages, respectively.

Fig. 2. Geological map of the Guanling landslide. a: Early Triassic Yongningzhen limestone; b: Early Triassic Yelang sandstone; c: Late Permian Longtan sandy shale; d: Permian basalt; e: Stratigraphic boundary; f: Fault; g: Landslide area; h: Guangzhao reservoir.

Fig. 3. (a): Source area of the landslide; (b): Stereo net graph of the discontinuities of rocks on the source area; (c) Outcrop measurements and orientations of discontinuities listed on the topography map. a: Landslide boundary; b: Source area; c: Stratigraphic boundary; d: Attitude of rock on the source area.

Fig. 4. Daily and cumulative rainfall in relation to Guanling landslide. Note that the peak rainfall was $260 \mathrm{~mm}$ on the day when the landslide occurred.

Fig. 5. Detailed topography of Guanling landslide. a: Landslide boundary; b: Source area; c: ERT survey lines; d: Cross section line; e: Boulder-sized debris; f: Gravel-sized debris; g: Silty with gravels in small size $(<5 \mathrm{~cm})$; h: Mudflow deposits.

Fig. 6. View of the source area. Three elevations are marked by red triangles.

Fig. 7. Views of the landslide deposits. a: Deposits on the source area and boulders in zone e in Fig. 5; b: Gravel-sized debris (zone f in Fig. 5); c: Silty with gravel-sized deposits (zone g in Fig. 5); d: Mudflow deposits (zone h in Fig. 5); e: Displaced materials deposited above the mudflow deposition.

Fig. 8. Grain-size distributions of silty soil from the silty soils dominant subzone of Guanling landslide.

Fig. 9. Deposit depth distribution at the different time steps of the DAN3D simulation. The contours of deposit depth are at 5-m interval. The elevation contours are at 20-m interval.

Fig. 10. Maximum velocities of landsliding along the runout path through simulation and the minimum velocity at differing two locations that were estimated through back-calculation using both run-up and superelevation data. The maximum velocity contours are at $5-\mathrm{m} / \mathrm{s}$ intervals. The elevation contours are at 20 - $\mathrm{m}$ intervals.

Fig. 11. Inferences from ERT-V and comparison with borehole data. White dashed line represents 
interpreted the hypothetical boundary of the landslide deposit.

590

591

Fig. 12. Longitudinal ERT profiles along the lines ERT1 to ERT3 shown in Fig. 5.

592

593

Fig. 13. Transverse ERT profiles along the lines ERT4 to ERT8 shown in Fig. 5.

594

595

Fig. 14. Final depth distribution (5-m of interval) of landslide deposits based on the numerical 596 simulation.

597

598

Fig. 15. Comparison of the landslide deposits depth from the ERT interpretation and DAN3D 599 simulation along several ERT lines of Fig. 14.

600

601

602

603

604

605

606

607

608

609

610

611

612

613

614

615

616

617

618

619

620

621

622

623

624 
Figures:

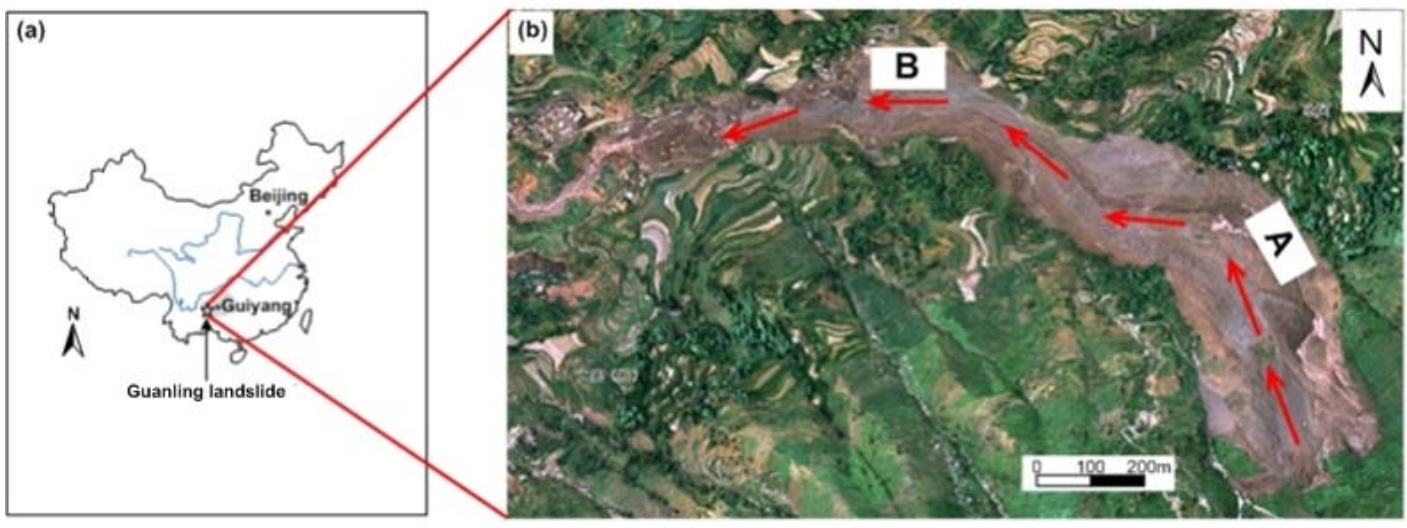

Fig. 1. (a) Location of the Guanling landslide; (b) Aerial view of the Guanling landslide where the red arrows express the landsliding direction; A and B: locations of Yongwo and Dazhai villages, respectively.

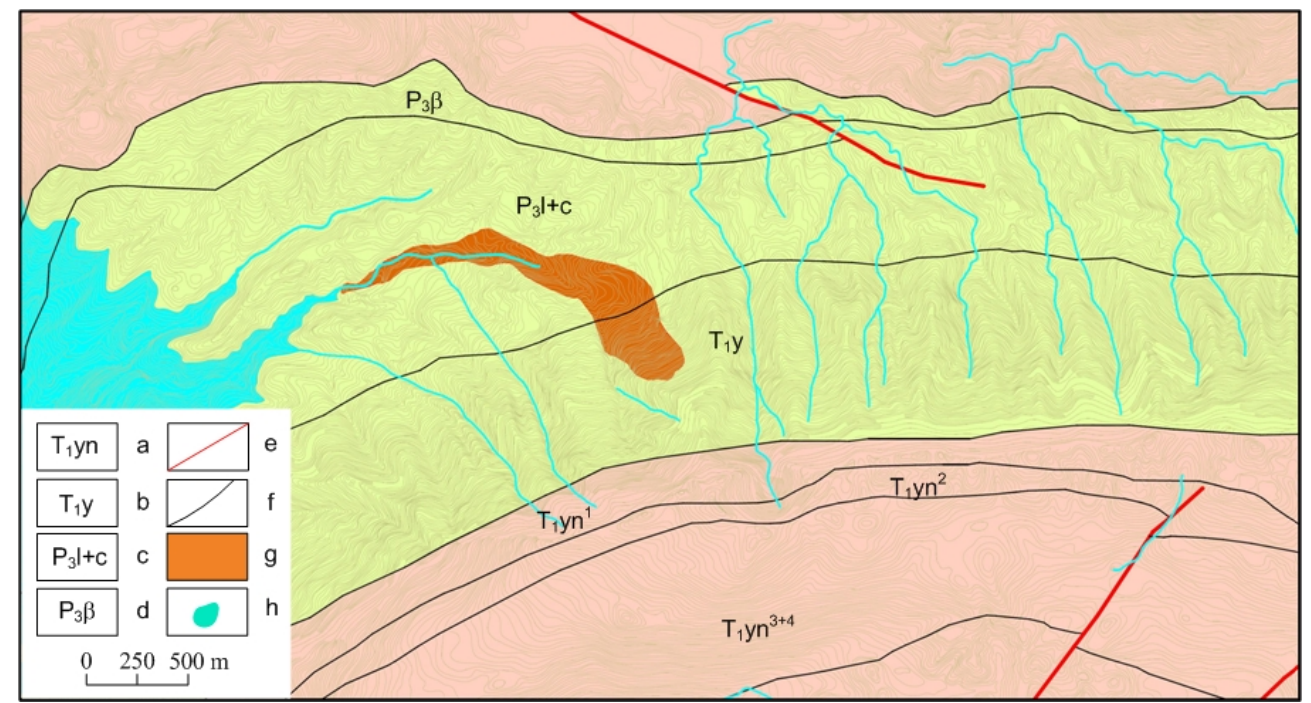

Fig. 2. Geological map of the Guanling landslide. a: Early Triassic Yongningzhen limestone; b: Early Triassic Yelang sandstone; c: Late Permian Longtan sandy shale; d: Permian basalt; e: Stratigraphic boundary; f: Fault; g: Landslide area; h: Guangzhao reservoir. 

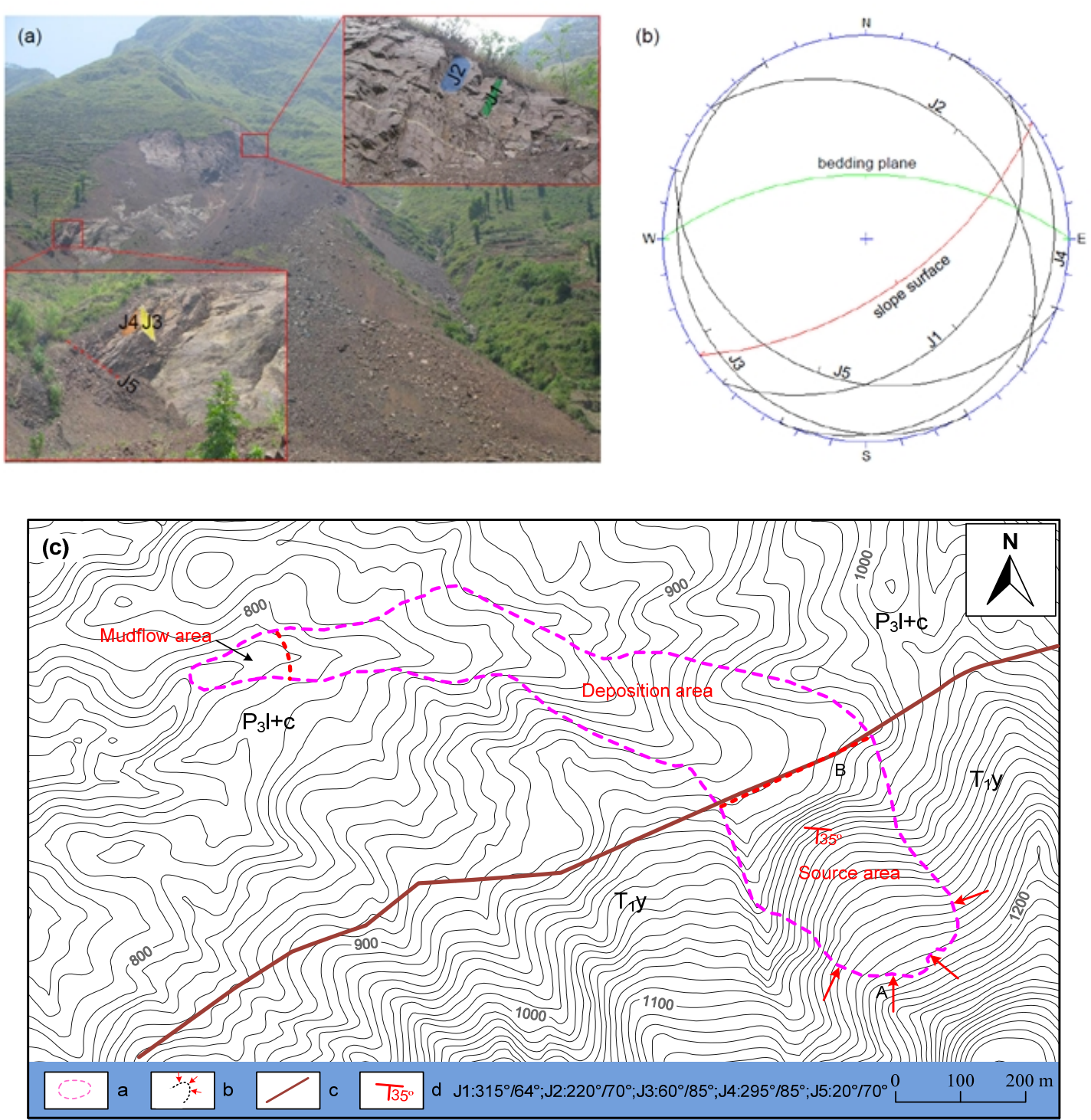

Fig. 3. (a): Source area of the landslide; (b): Stereonet graph of the discontinuities of rocks on the source area; (c) Outcrop measurements and orientations of discontinuities listed on the topography map. a: Landslide boundary; b: Source area; c: Stratigraphic boundary; d: Attitude of rock on the source area. 


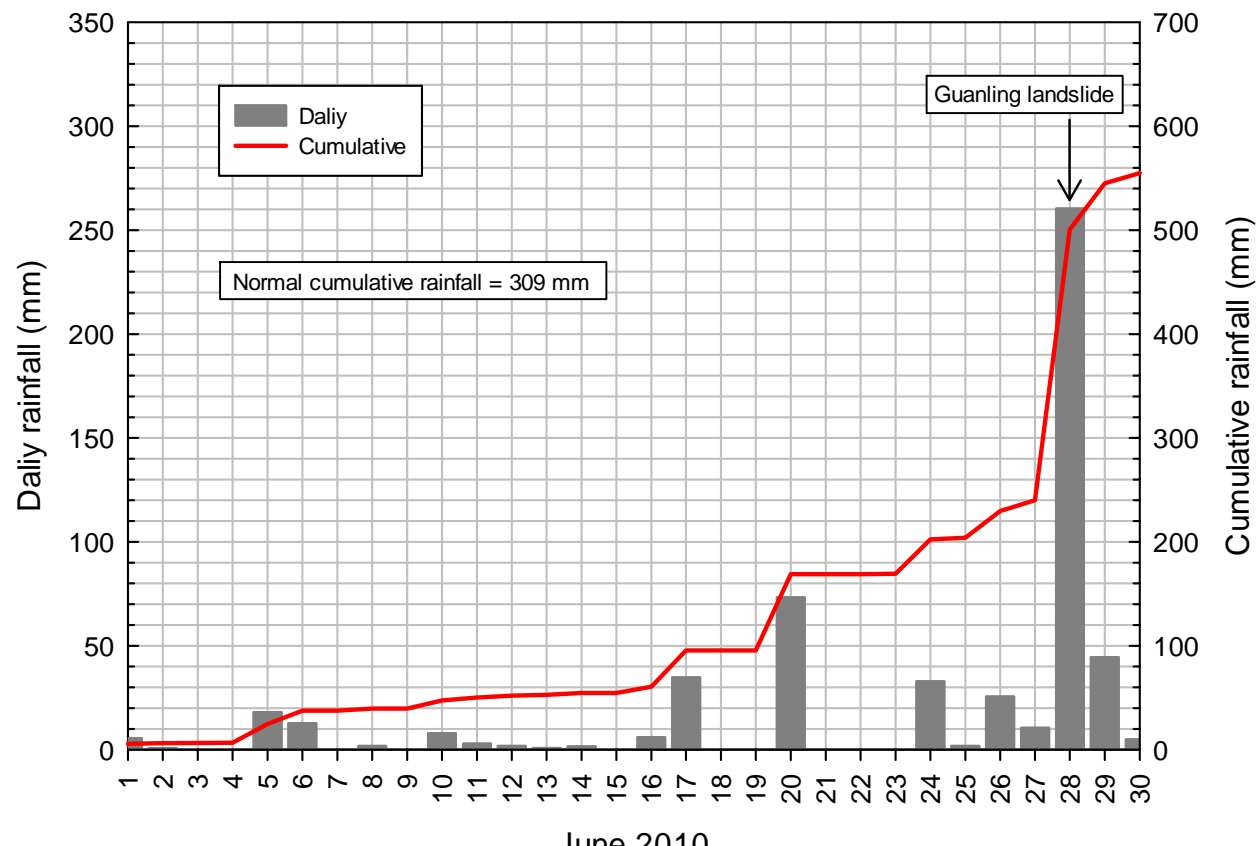

June 2010

Fig. 4. Daily and cumulative rainfall in relation to Guanling landslide. Note that the peak rainfall was $260 \mathrm{~mm}$ on the day when the landslide occurred.

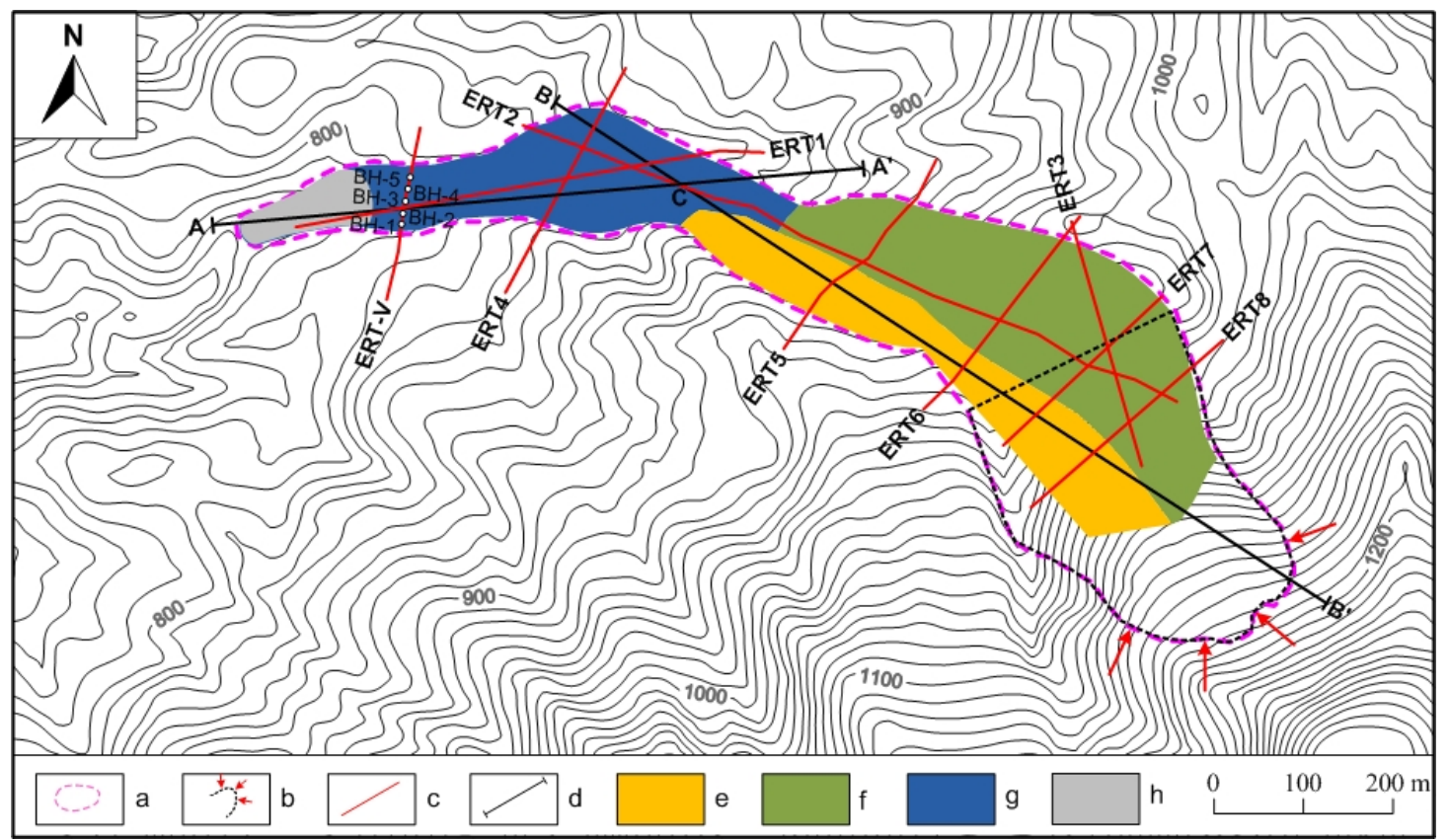

Fig. 5. Detailed topography of Guanling landslide. a: Landslide boundary; b: Source area; c: ERT survey lines; d: Cross section line; e: Boulder-sized debris; f: Gravel-sized debris; g: Silty with gravels in small size $(<5 \mathrm{~cm})$; h: Mudflow deposits. 


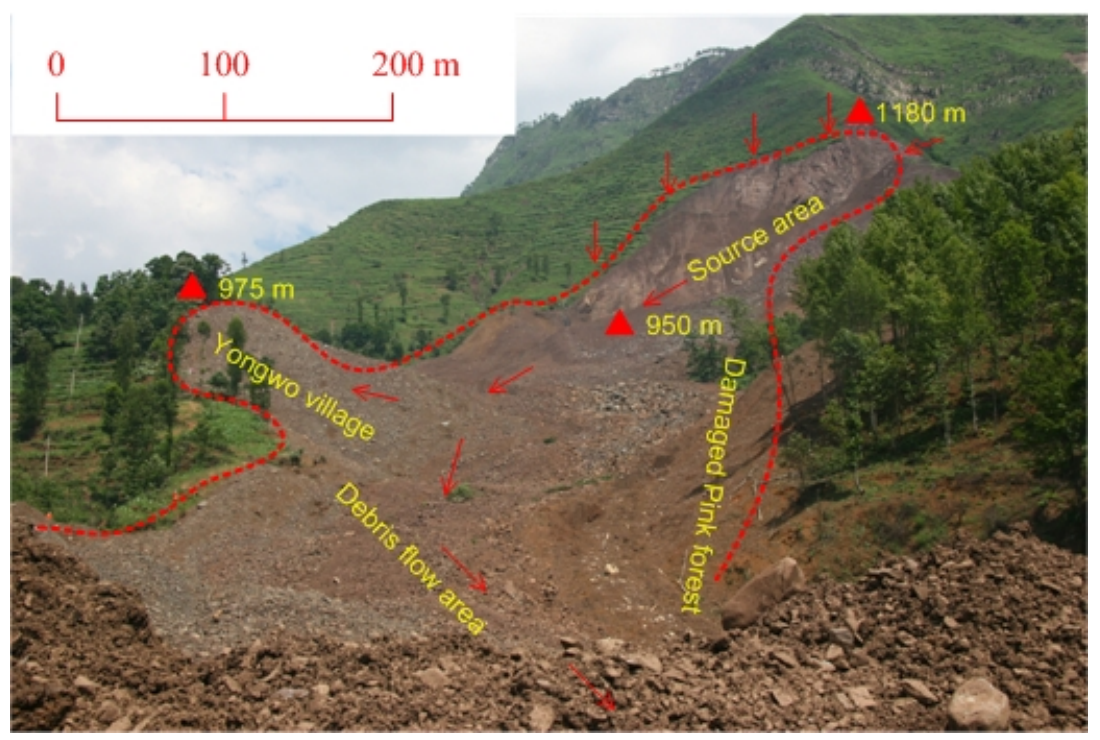

Fig. 6. View of the source area. Three elevations are marked by red triangles. 
(a)
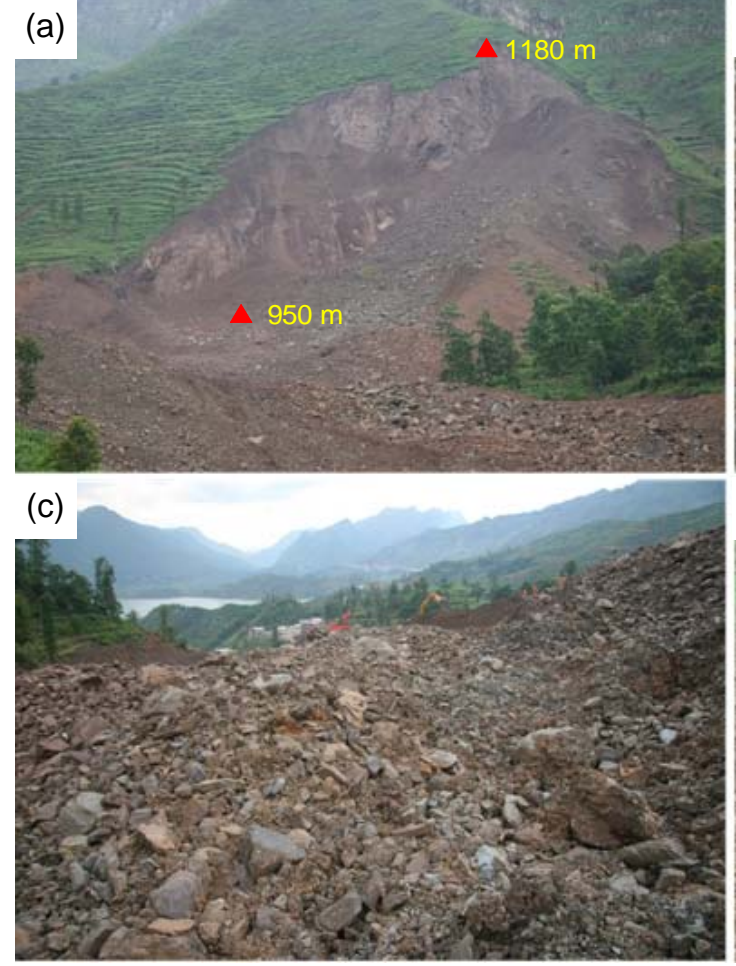

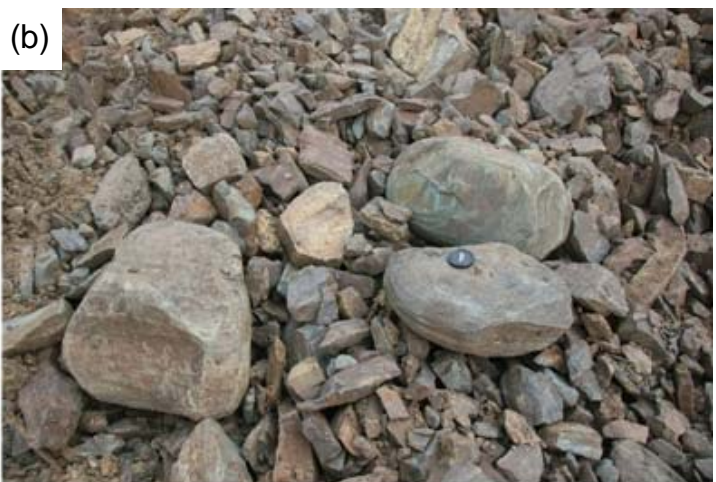

(d)

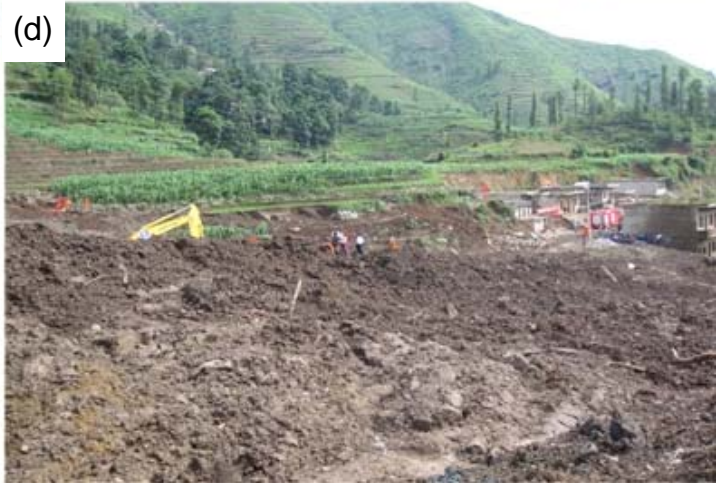

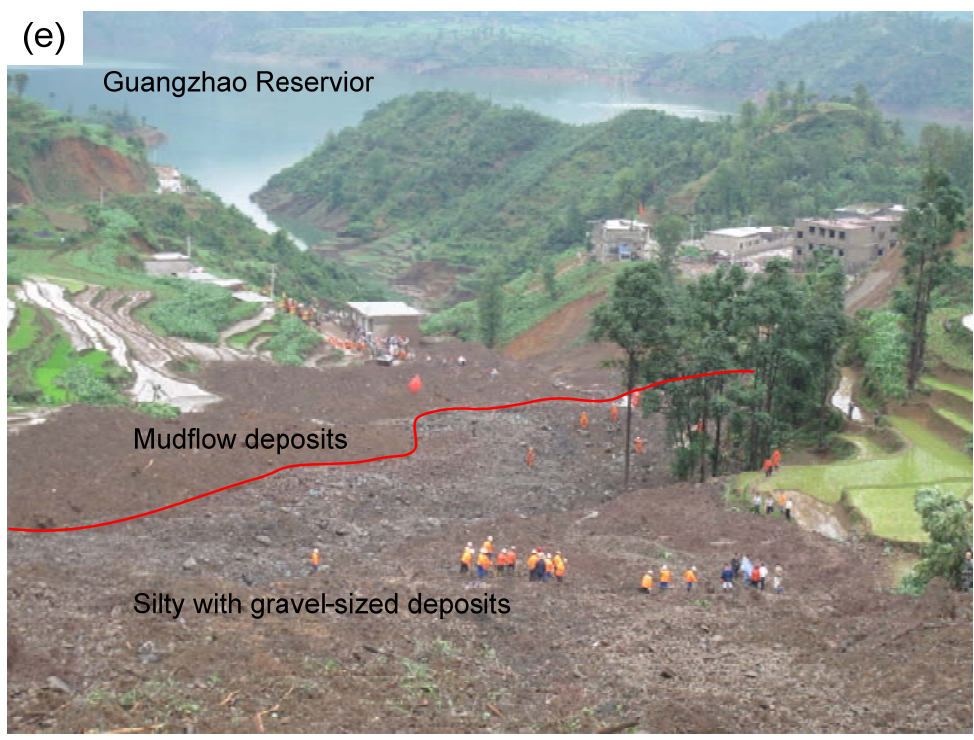

Fig. 7. Views of the landslide deposits. a: Deposits on the source area and boulders in zone e in Fig. 5; b: Gravel-sized debris (zone f in Fig. 5); c: Silty with gravel-sized deposits (zone g in Fig. 5); d: Mudflow deposits (zone h in Fig. 5); e: Displaced materials deposited above the mudflow deposition. 


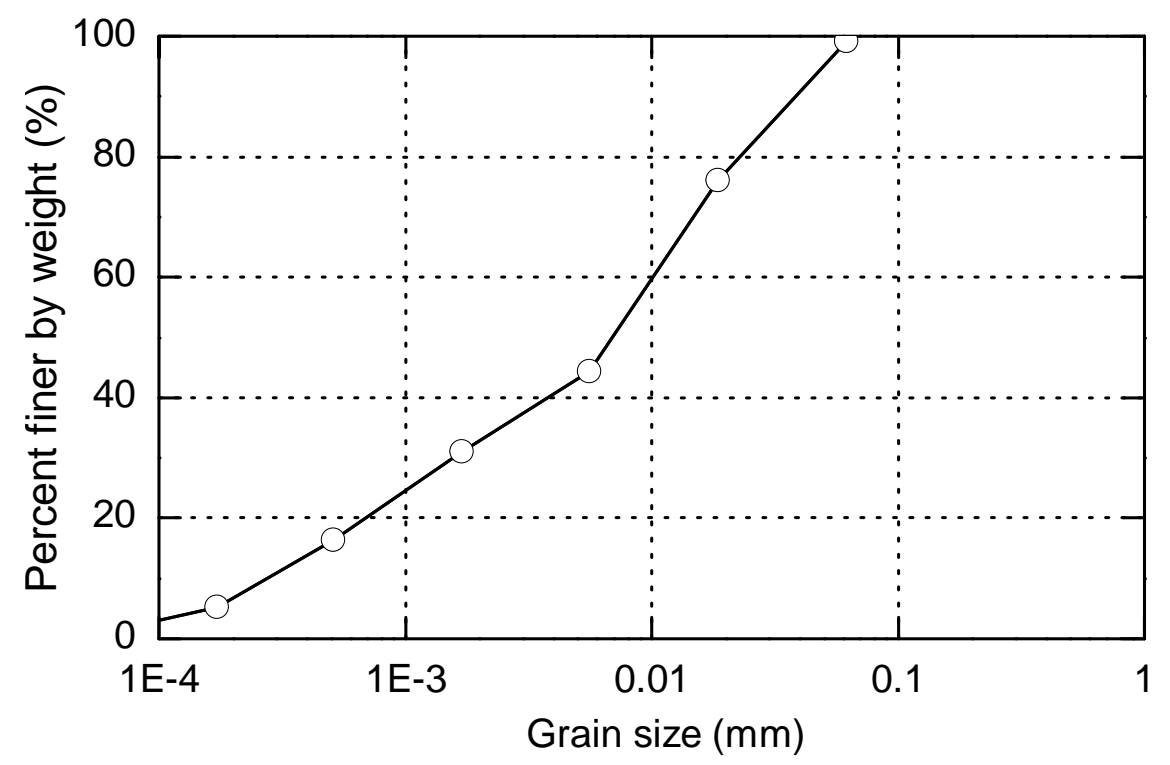

Fig. 8. Grain-size distributions of silty soil from the silty soils dominant subzone of Guanling landslide.
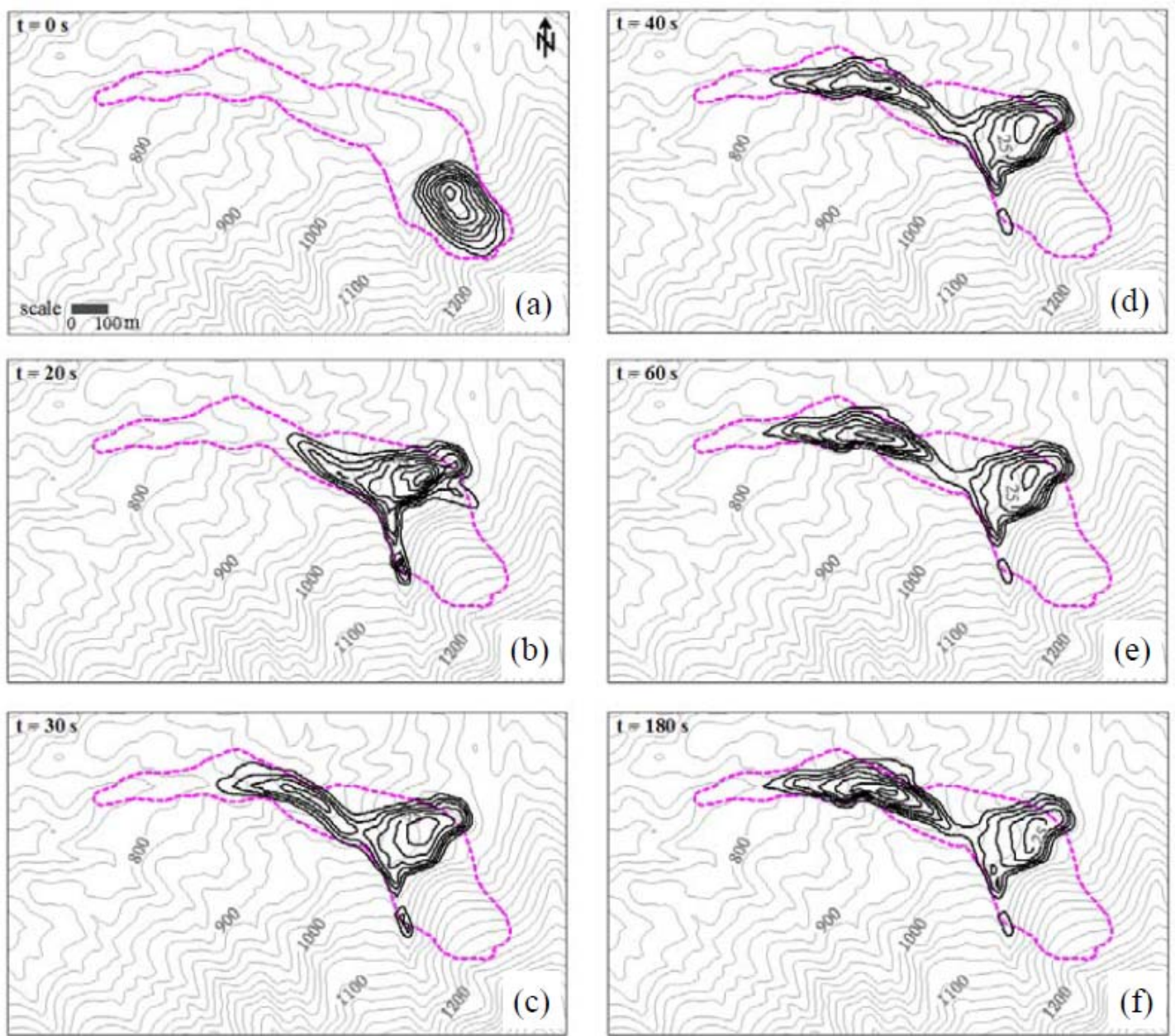

Fig. 9. Deposit depth distribution at the different time steps of the DAN3D simulation. The contours of deposit depth are at 5-m interval. The elevation contours are at 20-m interval. 


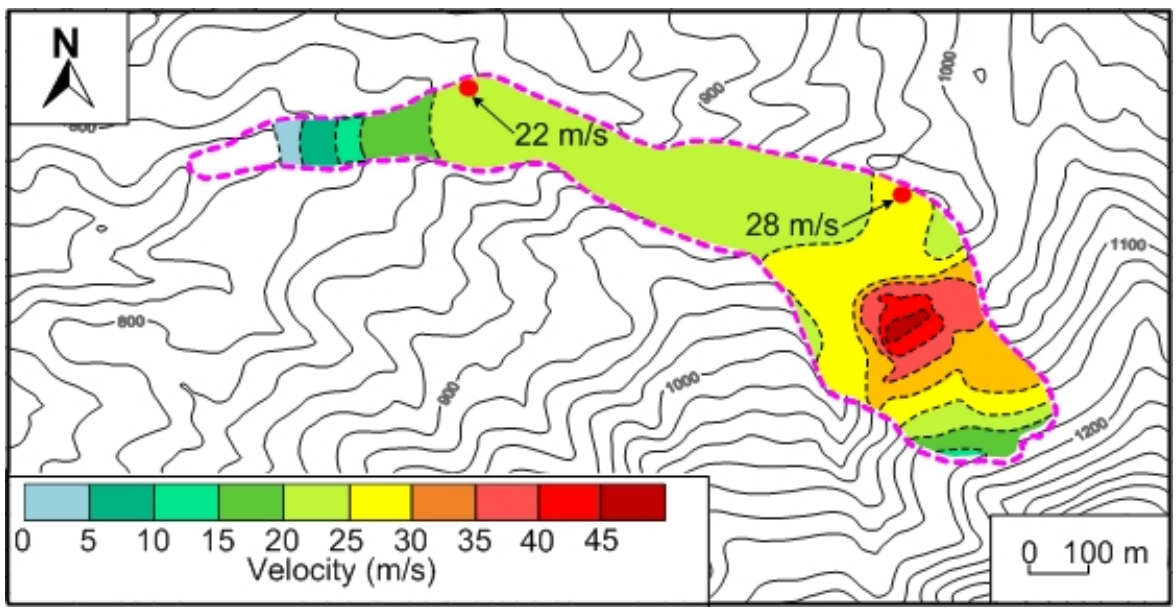

Fig. 10. Maximum velocities of landsliding along the runout path through simulation and the minimum velocity at differing two locations that were estimated through back-calculation using both run-up and superelevation data. The maximum velocity contours are at $5-\mathrm{m} / \mathrm{s}$ intervals. The elevation contours are at 20 -m intervals.

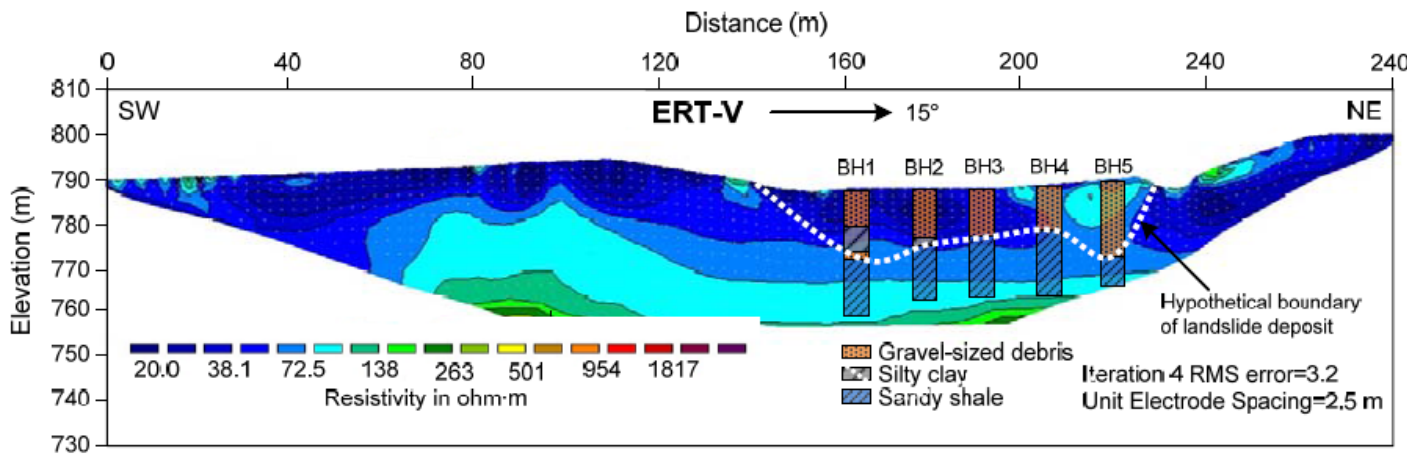

Fig. 11. Inferences from ERT-V and comparison with borehole data. White dashed line represents interpreted the hypothetical boundary of the landslide deposit. 


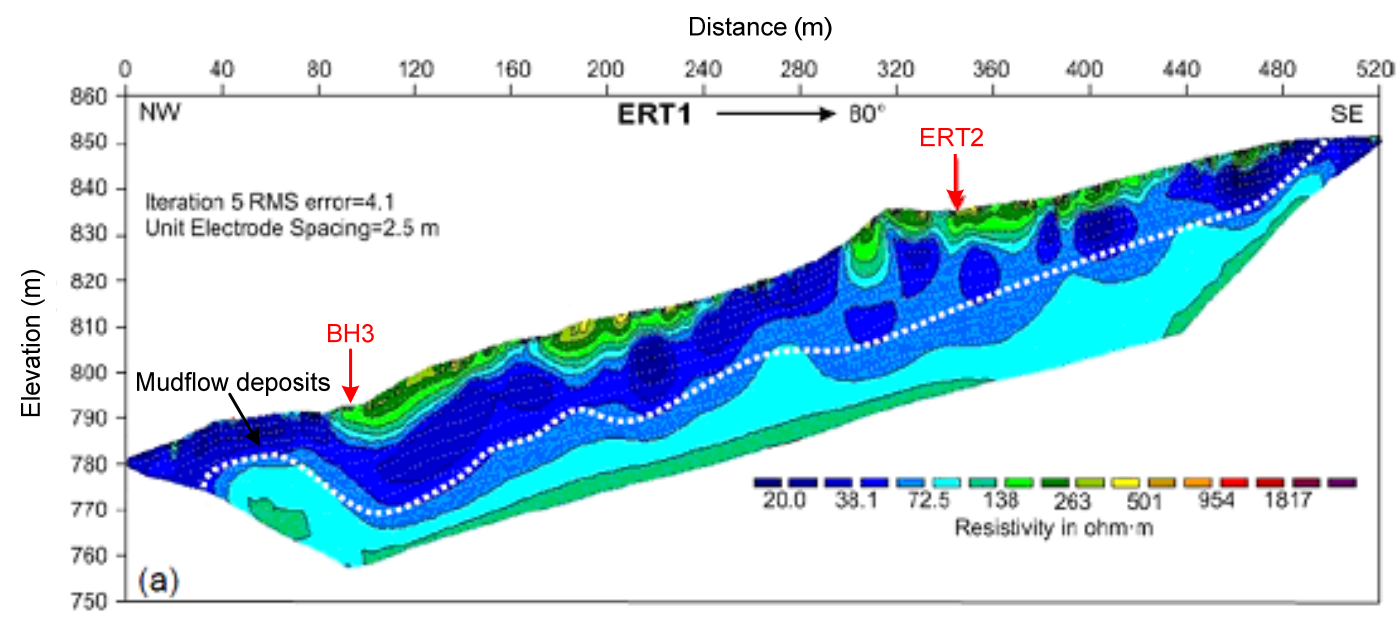

Distance (m)
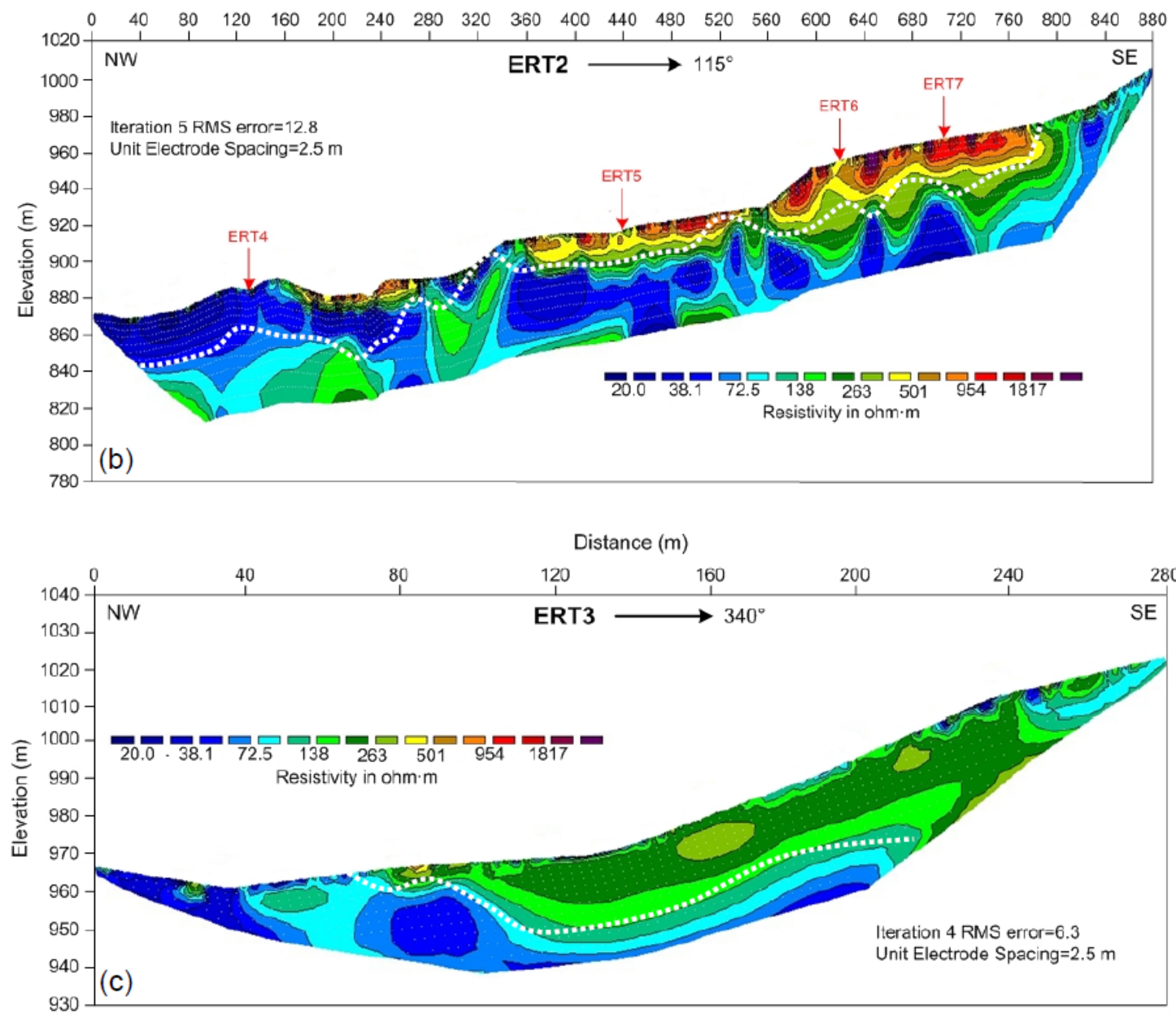

Fig. 12. Longitudinal ERT profiles along the lines ERT1 to ERT3 shown in Fig. 5. 

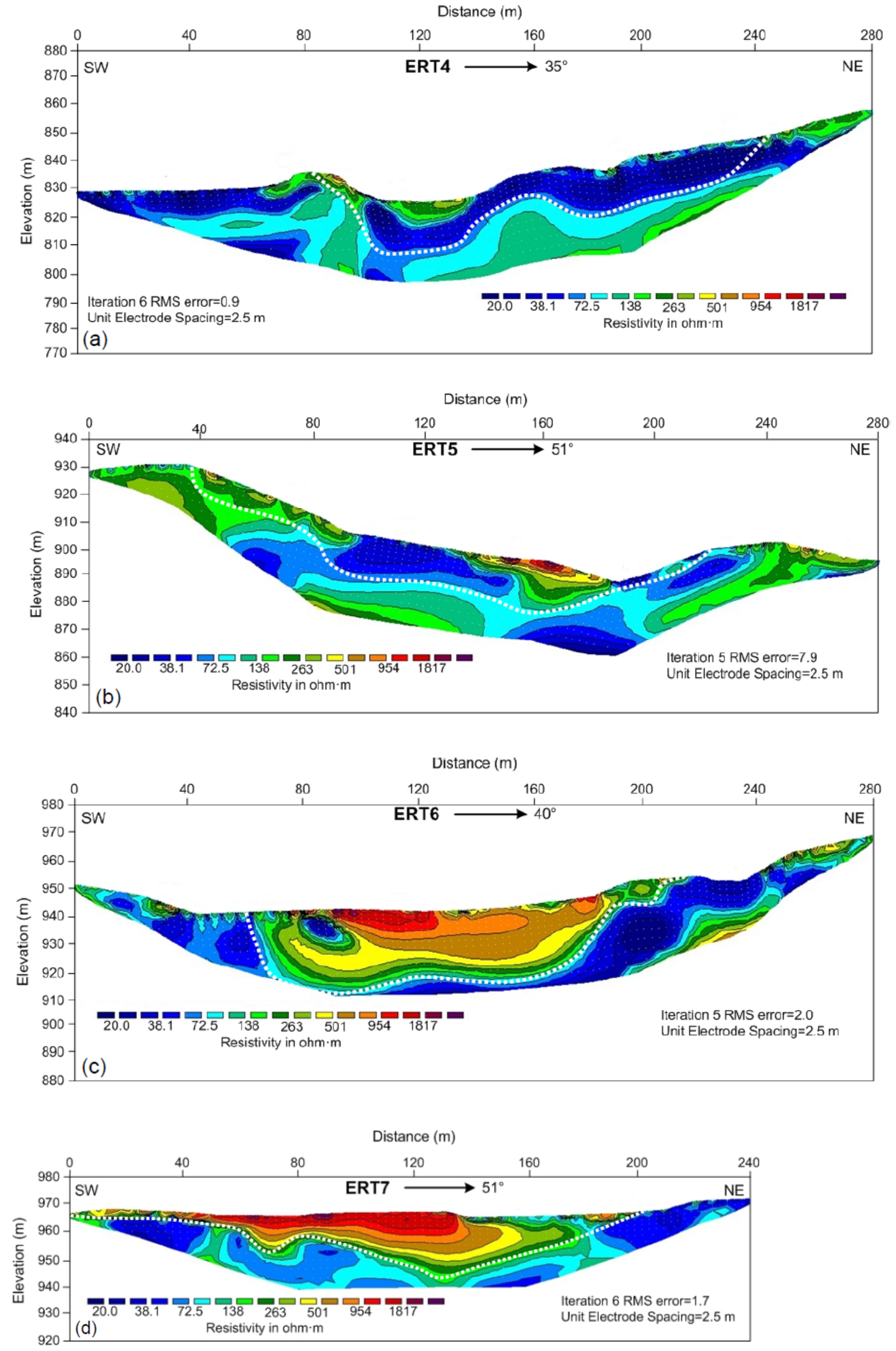


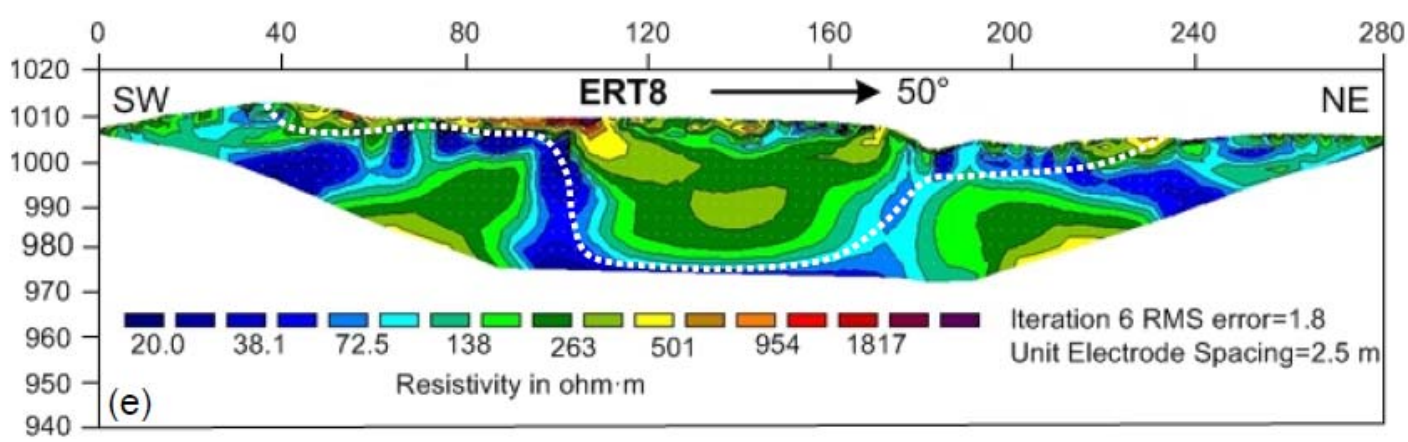

Fig. 13. Transverse ERT profiles along the lines ERT4 to ERT8 shown in Fig. 5.

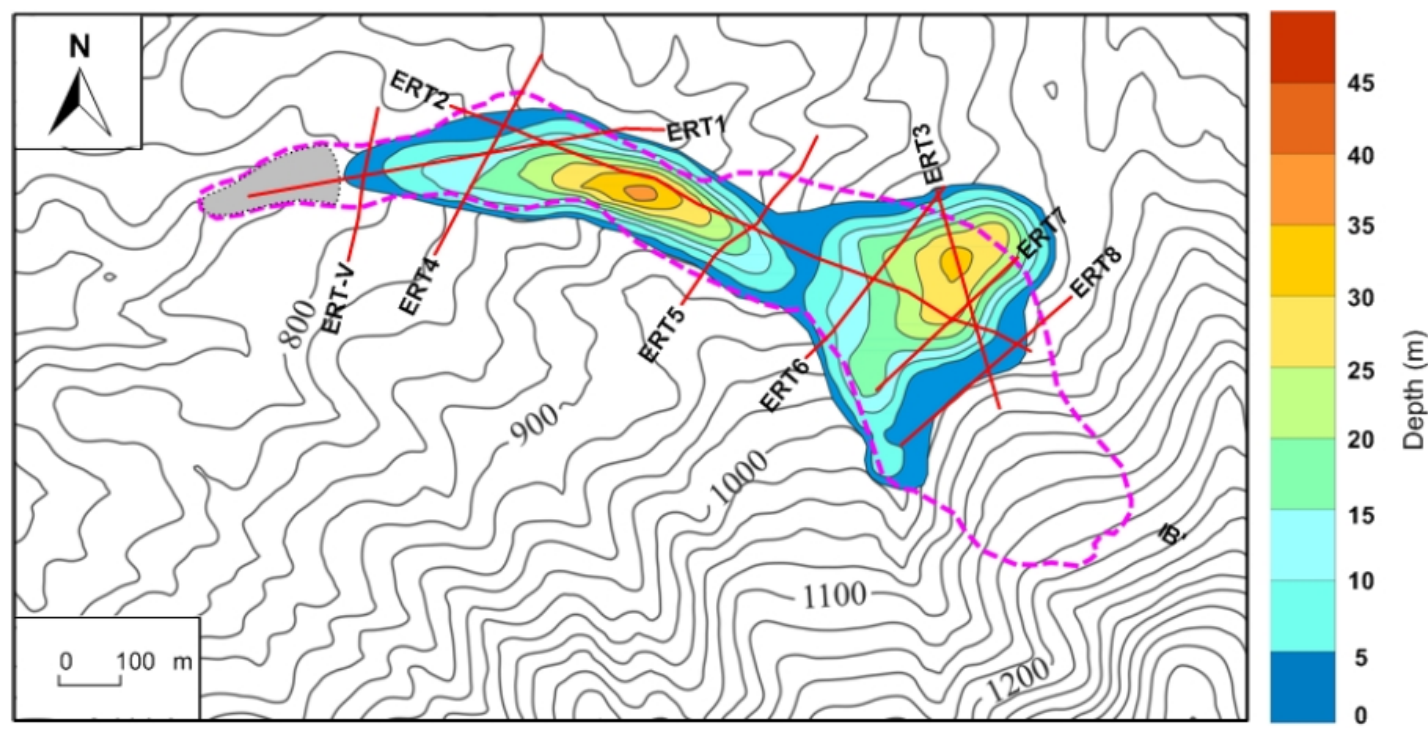

Fig. 14. Final depth distribution (5-m of interval) of landslide deposits based on the numerical simulation. 


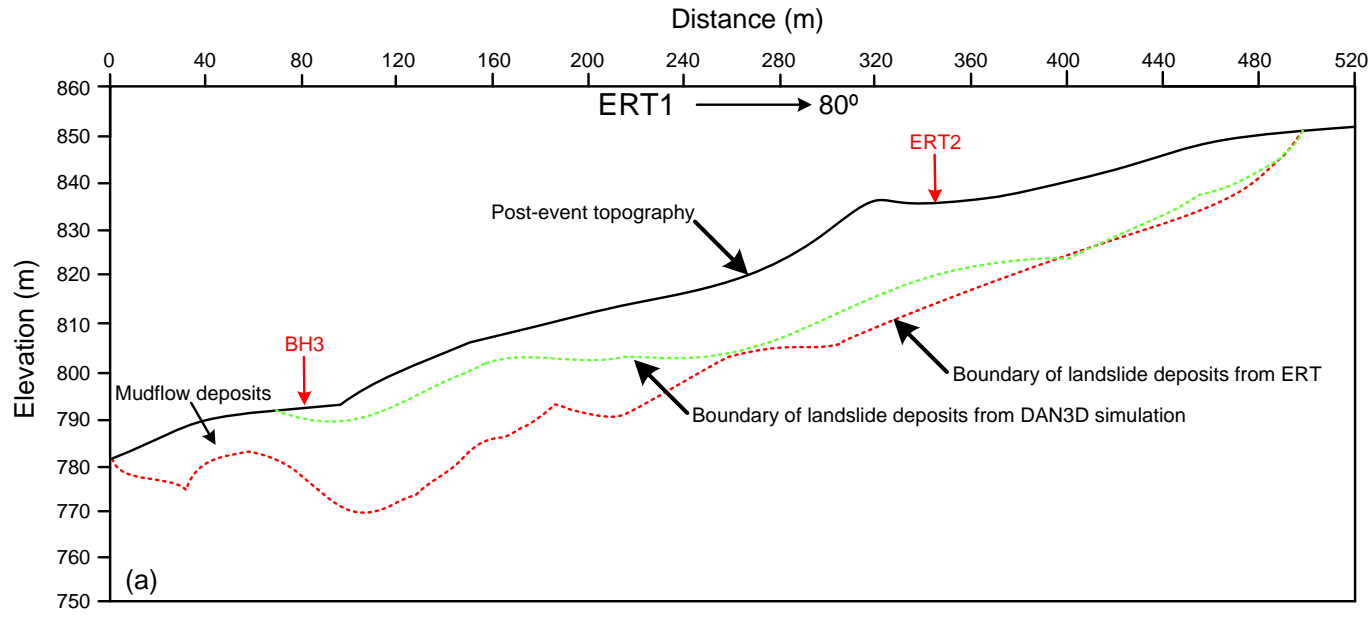

Distance $(\mathrm{m})$
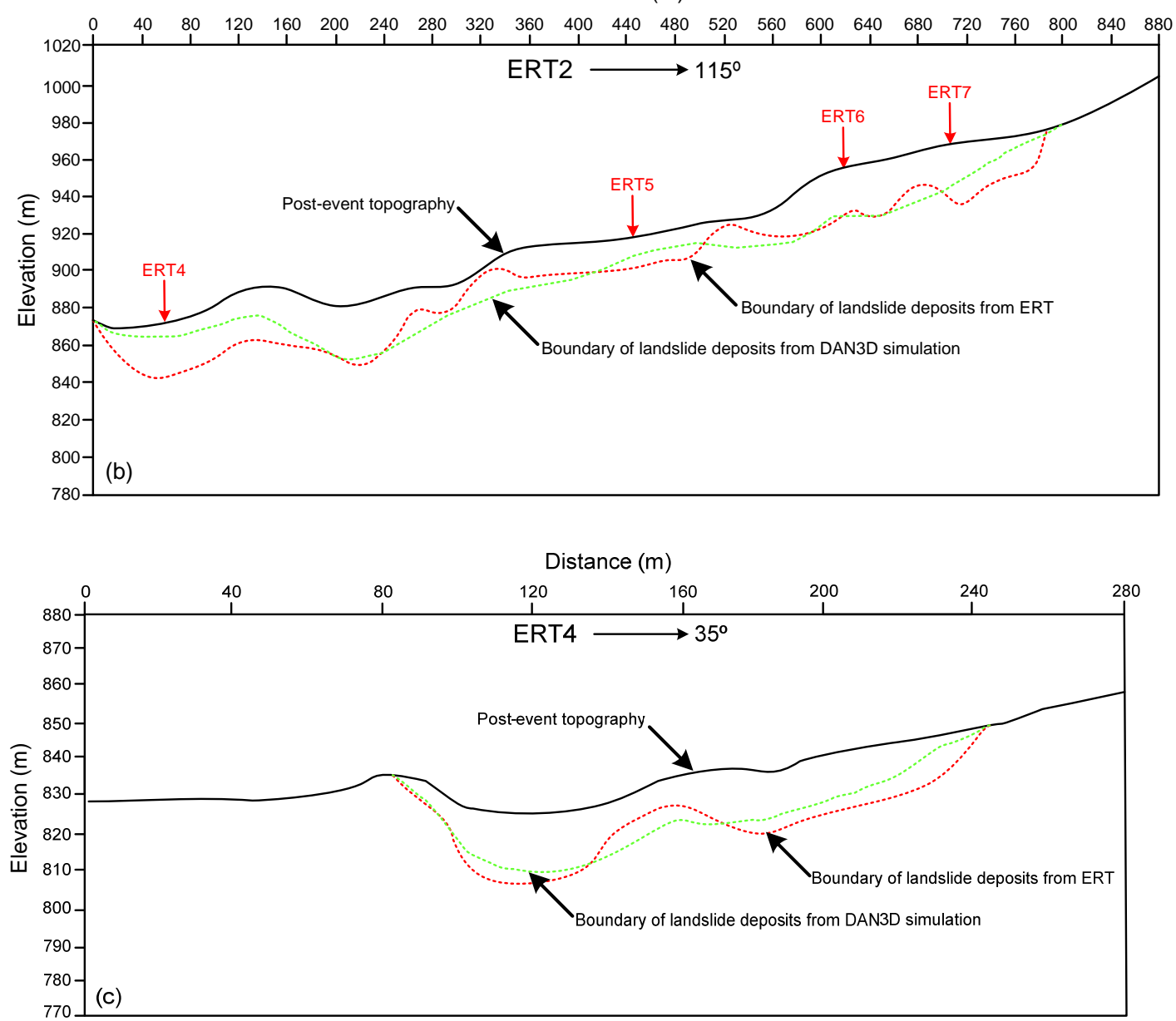


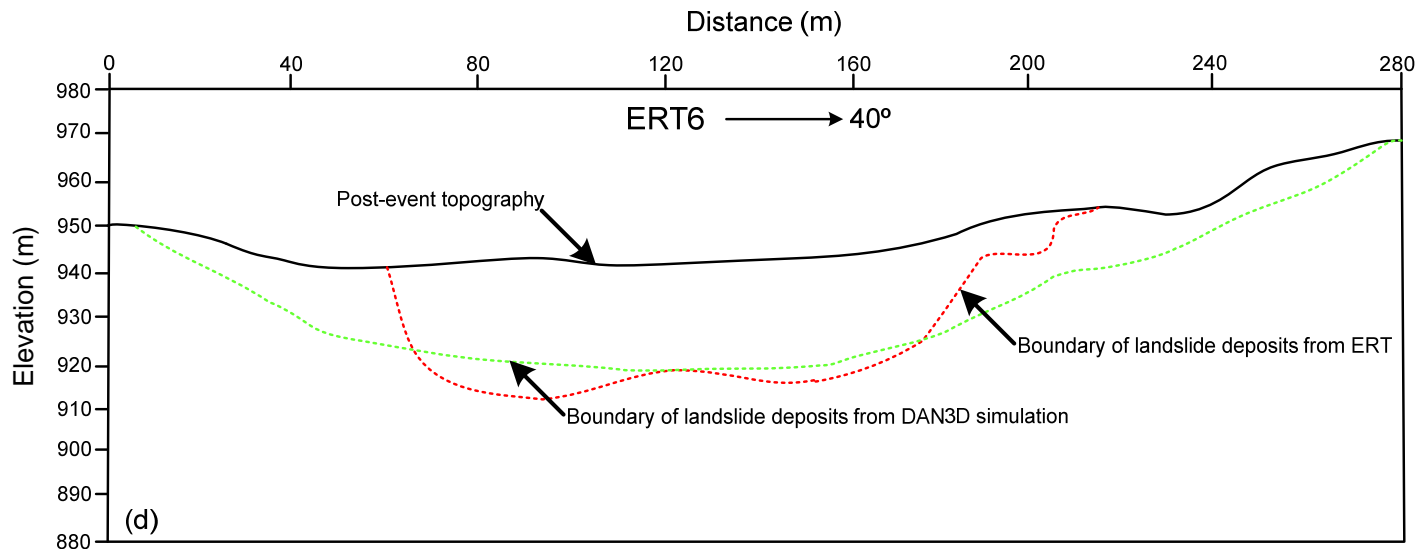

Fig. 15. Comparison of the landslide deposits depth from the ERT interpretation and DAN3D simulation along several ERT lines of Fig. 14. 